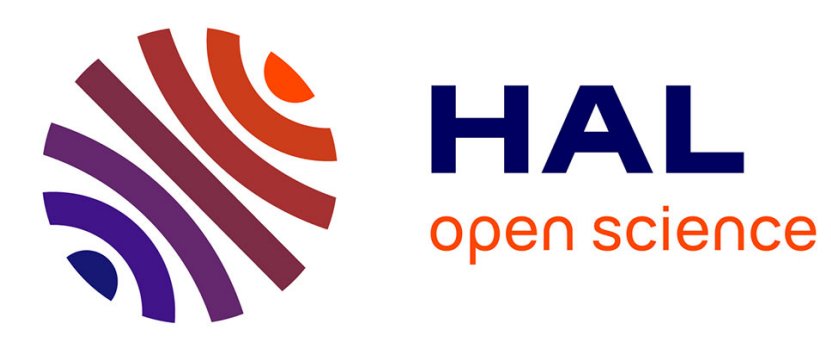

\title{
An Observational Study of Convection Initiation on 12 June 2002 during IHOP_2002
}

Tammy M. Weckwerth, Hanne V. Murphey, Cyrille Flamant, Janine Goldstein, Crystalyne R. Pettet

\section{To cite this version:}

Tammy M. Weckwerth, Hanne V. Murphey, Cyrille Flamant, Janine Goldstein, Crystalyne R. Pettet. An Observational Study of Convection Initiation on 12 June 2002 during IHOP_2002. Monthly Weather Review, 2008, 136 (7), pp.2283-2304. 10.1175/2007MWR2128.1 . hal-00321418

\section{HAL Id: hal-00321418 https://hal.science/hal-00321418}

Submitted on 26 Jan 2021

HAL is a multi-disciplinary open access archive for the deposit and dissemination of scientific research documents, whether they are published or not. The documents may come from teaching and research institutions in France or abroad, or from public or private research centers.
L'archive ouverte pluridisciplinaire HAL, est destinée au dépôt et à la diffusion de documents scientifiques de niveau recherche, publiés ou non, émanant des établissements d'enseignement et de recherche français ou étrangers, des laboratoires publics ou privés. 


\title{
An Observational Study of Convection Initiation on 12 June 2002 during IHOP_2002
}

\author{
TAMMY M. WECKWERTH \\ Earth Observing Laboratory, National Center for Atmospheric Research,* Boulder, Colorado \\ HANNe V. MuRphey \\ Department of Atmospheric Sciences, University of California, Los Angeles, Los Angeles, California
}

Cyrille Flamant

Institute Pierre-Simon Laplace/Service d'Aéronomie, Centre National de la Recherche Scientifique, Université Pierre et Marie Curie, Paris, France

JANINE GOLDSTEIN

Earth Observing Laboratory, National Center for Atmospheric Research, * Boulder, Colorado

Crystalyne R. Pettet

National Weather Service, Indianapolis, Indiana

(Manuscript received 22 December 2006, in final form 11 October 2007)

\begin{abstract}
The International $\mathrm{H}_{2} \mathrm{O}$ Project (IHOP_2002) was designed to sample the three-dimensional time-varying moisture field to better understand convective processes. Numerous research and operational water vapor measuring systems and retrievals, via in situ and remote sensing techniques, were operated in the U.S. Southern Great Plains from 13 May to 25 June 2002. This was done in combination with more traditional observations of wind and temperature. Convection initiation (CI) sampling strategies were designed to optimally employ the array of ground-based and airborne sensors to observe the processes leading to the development of deep, moist convection. This case study examines several clear-air features and their impact on CI on 12 June 2002. The supercells that developed produced damaging winds and hail. The clear-air, preconvective features included (i) a mesoscale low pressure region, (ii) a dryline, (iii) an old outflow boundary, (iv) the intersection of (ii) and (iii), (v) internal gravity waves, and (vi) horizontal convective rolls.

A unique combination of instruments was positioned to sample the preconvective environment on 12 June 2002. The Lidar pour l'Etude des Interactions Aérosols Nuages Dynamique Rayonnement et du Cycle de l'Eau (LEANDRE II) water vapor differential absorption lidar (DIAL), the airborne Electra Doppler Radar (ELDORA), and the Navy Research Laboratory (NRL) P3 aircraft in situ measurements provided information on the moisture and vertical velocity distribution within the boundary layer. Radiosondes, dropsondes, wind profilers, and an Atmospheric Emitted Radiance Interferometer (AERI) provided temperature, moisture, and wind profiling information. Although other ground-based sensors (i.e., S-band dual-polarization Doppler radar, Mobile Integrated Profiling System) were 50-150 km west of the CI area, they were useful for illustrating the boundary layer kinematics and reflectivity fields.

Results suggest that the mesolow and mesoscale boundaries, respectively, acted to enhance the low-level moisture advection and convergence in the CI region. While internal gravity waves were present and appeared to modulate water vapor along the old outflow boundary, they did not play an obvious role in CI in this case. Horizontal convective rolls were observed beneath the new storms that initiated and may have helped to focus the CI in this case.
\end{abstract}

* The National Center for Atmospheric Research is sponsored by the National Science Foundation.

Corresponding author address: Tammy M. Weckwerth, Earth Observing Laboratory, National Center for Atmospheric Research, P.O. Box 3000, Boulder, CO 80307-3000.

E-mail: tammy@ucar.edu 


\section{Introduction}

Improved understanding of the factors that influence the timing and location of new deep, moist convection is important for weather forecasting purposes. In nonsynoptically forced environments, low-level convergence zones are known to be preferred locations for convective development (e.g., Byers and Braham 1949; Purdom and Marcus 1982; Wilson and Schreiber 1986); however, predicting where, when, and if convection will develop along the boundaries is difficult. This paper presents a case study with multiple boundaries and boundary layer circulations and their interactions that led to deep, moist convection. These preconvective features include a mesolow circulation, a dryline, an old outflow boundary, the intersection between the dryline and the old outflow boundary, internal gravity waves, and horizontal convective rolls. The processes that dictate the impact of these preconvective features in initiating storms and determining where and when storms form are not well understood, partially owing to a lack of observations at the scales necessary to resolve these features. This paper will address the importance of these preconvective features on the timing and location of convection initiation (CI) on 12 June 2002.

Past work has shown that intersections between various low-level boundaries are more likely to be the locations for convective development, partially due to relatively deeper low-level convergence and moisture at the intersections. Such boundary interactions include cold fronts with drylines (e.g., Bluestein et al. 1990; Weiss and Bluestein 2002); cold fronts with undular bores (e.g., Karyampudi et al. 1995; Koch and Clark 1999); gust fronts with sea-breeze fronts (e.g., Carbone et al. 2000; Kingsmill 1995; Kingsmill and Crook 2003); gust fronts with internal gravity waves (e.g., Weckwerth and Wakimoto 1992); gust fronts with gust fronts (e.g., Mahoney 1988); and horizontal convective rolls with cold fronts (e.g., Trier et al. 1991), gust fronts (e.g., Fankhauser et al. 1995), sea-breeze fronts (e.g., Wakimoto and Atkins 1994; Atkins et al. 1995; Dailey and Fovell 1999; Fovell and Dailey 2001), drylines (e.g., Atkins et al. 1998; Trier et al. 2004; Xue and Martin 2006), and stationary boundaries (e.g., Crook et al. 1991; Wilson et al. 1992).

Many studies have illustrated the importance of horizontal convective rolls in CI. For example, in a study of the sea-breeze front intersecting horizontal convective rolls, enhanced updrafts and clouds were observed due to increased lifting at the intersection regions (Wakimoto and Atkins 1994; Atkins et al. 1995). Two detailed observational case studies (Atkins et al. 1995) and numerical simulations (Dailey and Fovell 1999;
Fovell and Dailey 2001) compared and contrasted rolls both normal and parallel to a sea-breeze front. They found that the rolls were critical in determining the spacing of convective clouds and affected the likelihood of CI. Furthermore, it has been suggested that the interactions between internal gravity waves propagating within the inversion layer at the top of the boundary layer with roll circulations within the boundary layer can initiate deep convection (e.g., Balaji and Clark 1988; Redelsperger and Clark 1990). Observations in east-central Florida during the Convection and Precipitation/Electrification (CaPE; e.g., Wakimoto and Atkins 1994) project showed that rolls alone may be capable of initiating deep convection, even in the absence of other more prominent mesoscale boundaries (Weckwerth 2000).

In studying CI, it is not only important to identify boundary locations but also to accurately measure the mesoscale wind profiles and stability estimates. The balance between opposing signs of low-level wind shear is important for the generation and sustenance of deep convection (Rotunno et al. 1988; Lee et al. 1991). The relationship between the low-level shear and the winds aloft is also critical for storm initiation. That is, the airflow within the new cells aloft should be comparable to that of the boundary motion beneath (e.g., Lee et al. 1991; Wilson and Megenhardt 1997). Furthermore it is important to understand the thermodynamics of the environment (e.g., Lee et al. 1991; Crook 1996). In a modeling study by Crook (1996), for example, it was shown that small horizontal variations in the boundary layer temperature and moisture determined whether or not storms would initiate and significantly impacted the strength of the storms that did develop. Current stateof-the-art short-term nowcasting systems utilize these predictor fields in an attempt to predict where and when storms will form, with some success (Mueller et al. 2003). Subsequently, the International $\mathrm{H}_{2} \mathrm{O}$ Project (IHOP_2002) CI dataset was designed to monitor not only the boundaries, but also winds and thermodynamics in the ambient environment (Weckwerth and Parsons 2006).

The complete set of measurements, including boundary locations, winds, temperature, and moisture, is particularly valuable in the study of CI on 12 June 2002 because storms did not form directly along a boundary or at an intersection region. Instead, they initiated about $20 \mathrm{~km}$ southeast of the intersection region. The goal of this study is to identify the most critical factors that led to $\mathrm{CI}$ at this location, including locations of boundaries and circulations, thermodynamics, and winds.

Section 2 will describe the IHOP_2002 data and 
methodology relevant to this study. Section 3 will present a brief synoptic and mesoscale overview of 12 June 2002, and section 4 will present details of the boundaries and circulations and their potential impact on CI. Cell-tracking results will be presented in section 5 and a summary and conclusions will be given in section 6.

\section{Data and methodology}

IHOP_2002 was designed to sample the threedimensional time-varying moisture field to better understand convective processes. Numerous research and operational water vapor measuring systems and retrievals, via in situ and remote sensing techniques, were operated in the U.S. Southern Great Plains from 13 May to 25 June 2002. This was done in combination with the more standard observations of wind and temperature (Weckwerth et al. 2004). Convection initiation sampling strategies were designed to maximize observational overlap from multiple instruments to better understand the processes leading to the development of deep, moist convection (Weckwerth and Parsons 2006).

This manuscript will focus on a subset of the extensive suite of IHOP_2002 instruments. Geostationary Operational Environmental Satellite-11 (GOES-11) $1-\mathrm{km}$ visible satellite imagery was obtained every $\sim 5$ min during this case study on 12 June 2002 . The illustration of the cloud field development is a critical component for nowcasting CI (e.g., Wilson and Mueller 1993; Kingsmill 1995; Hane et al. 1987; May 1999). Composite radar displays were created every $10 \mathrm{~min}$ using the low-level Weather Surveillance Radar-1988 Doppler (WSR-88D) level II radar data and the National Center for Atmospheric Research's (NCAR's) S-band dual-polarization Doppler radar (S-Pol) research radar (Lutz et al. 1995) data. These composites were useful for monitoring the various clear-air boundaries prior to CI. The composites were particularly valuable for this case study because the CI occurred near the maximum range of both S-Pol and the Vance Air Force Base, Oklahoma, WSR-88D radars. Thus, the combination of multiple radars provides more complete coverage than would be available from an individual radar. A modeling study showing the positive impact of radar data assimilation on quantitative rainfall forecasts for this day is discussed in Xiao and Sun (2007).

Two dropsonde (Hock and Franklin 1999) legs were performed from a dedicated dropsonde aircraft, the Flight International Learjet. The first leg began at 1918 $\mathrm{UTC}(\mathrm{UTC}=\mathrm{LT}+5 \mathrm{~h}), \sim 90 \mathrm{~min}$ prior to CI, and the second series of drops commenced at 2047 UTC just prior to the $\sim 2100$ UTC initiation time. Many mobile radiosonde launches were also released during this critical preconvective time period. The Mobile Integrated Profiling System (MIPS; Knupp et al. 2000) provided vertical wind profiles west of the CI location along the northern edge of the old outflow boundary. An Atmospheric Emitted Radiance Interferometer (AERI; Feltz et al. 2003) provided continuous profiles of temperature and moisture south of the CI location.

Many other supplementary instruments were operating on this day (e.g., mobile radars, mobile mesonets, and a mobile radiometer) but were positioned too far to the west to capture information on CI. Analyses of these data have been published in a case study discussing the null $\mathrm{CI}$ event in the region to the west by Markowski and Hannon (2006) and Markowski et al. (2006). Markowski et al. (2006) showed that the updrafts were neither sufficiently deep nor strong to penetrate the level of free convection (LFC) in the region to the west, and thus CI did not occur there.

The Naval Research Laboratory (NRL) P3 aircraft did fly numerous flight legs in the CI region. It was uniquely equipped with the Electra Doppler Radar (ELDORA), NCAR's airborne Doppler radar (Hildebrand et al. 1996), and Lidar pour l'Etude des Interactions Aérosols Nuages Dynamique Rayonnement et du Cycle de l'Eau (LEANDRE II), a horizontal-pointing water vapor differential absorption lidar (DIAL; Bruneau et al. 2001). This creative combination of instruments provided for an unprecedented view of the water vapor field in the context of the airborne dual-Doppler wind measurements.

The methodology for ELDORA analyses are similar to that done in previous studies and will be described briefly here (e.g., Wakimoto et al. 1998; Cai et al. 2006). First, the radar data were carefully corrected for navigational errors (e.g., Lee et al. 1994; Testud et al. 1995; Bosart et al. 2002) and then edited to remove ground clutter and sidelobes using the SOLO II software package (Oye et al. 1995). The along-track and sweep-angle resolution for ELDORA during IHOP_2002 were $\sim 550 \mathrm{~m}$ and $1.5^{\circ}$, respectively, which led to an effective vertical sampling of $\sim 250 \mathrm{~m}$ at a distance of $10 \mathrm{~km}$ from the flight track. The data were interpolated onto a regular Cartesian grid using a horizontal and vertical grid spacing of 600 and $300 \mathrm{~m}$, respectively. A Cressman filter (Cressman 1959), with a radius of influence of 600 $\mathrm{m}$ in the horizontal and $450 \mathrm{~m}$ in the vertical, was applied in the interpolation process. The lowest level for the analyses was chosen to be $400 \mathrm{~m}$ AGL. Because of the complex nature of multiple boundaries with different motions on this day and to the slow motion of the boundaries, the ELDORA analyses were not time- 


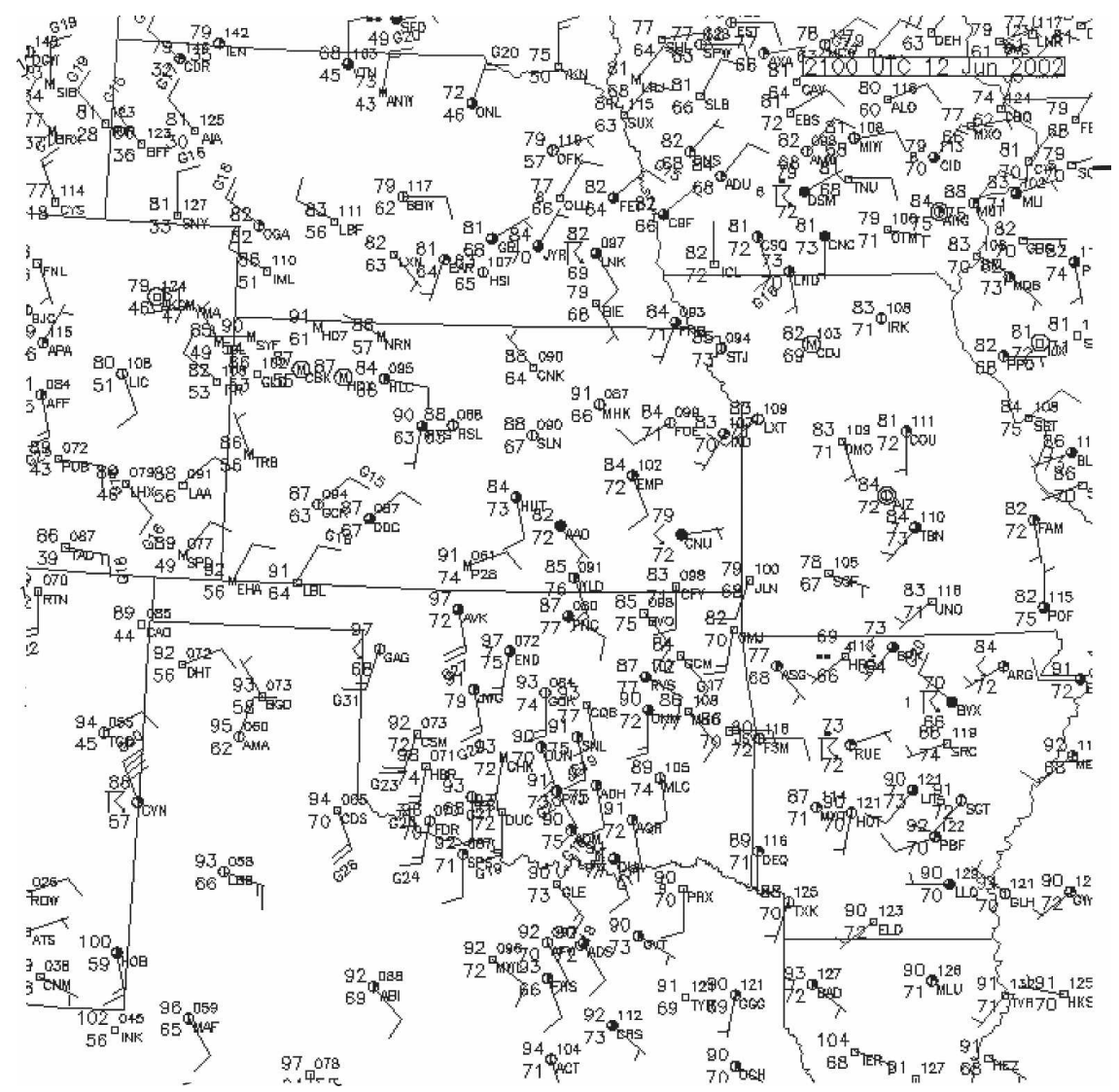

FIG. 1. Surface pressure analysis at 2100 UTC 12 Jun 2002. Standard surface station measurements are plotted with temperature, dewpoint temperature, pressure, and winds.

space adjusted. The Custom Editing and Display of Reduced Information in Cartesian space (CEDRIC; Mohr and Miller 1983; Mohr et al. 1986) software package was used to perform the dual-Doppler wind synthesis using a two-step Leise (1982) filter. The filter effectively removes any wavelengths less than $2.4 \mathrm{~km}$ and damps wavelengths less than $3.6 \mathrm{~km}$. Vertical velocity was obtained by upward integration of the anelastic continuity equation with errors estimated to be less than 1-2 $\mathrm{m} \mathrm{s}^{-1}$ (Wilson et al. 1994).

The horizontal-pointing LEANDRE II data were analyzed using a 5-s averaging time to create an alongtrack resolution of $\sim 500 \mathrm{~m}$. The along-beam resolution in the range between 0.8 and $2.8 \mathrm{~km}$ from the aircraft was $300 \mathrm{~m}$. The water vapor data were only available in this limited range because of strong water vapor absorption of the lidar signal within the CBL. The LEANDRE II water vapor fields were computed by interpolating the data onto a Cartesian grid using a horizontal grid spacing of $600 \mathrm{~m}$ with a smoothing parameter of $800 \mathrm{~m}$ in the along-track direction. The ELDORA and LEANDRE II analyses were then interpolated and combined onto a $600-\mathrm{m}$ grid, providing complementary moisture and kinematic information, similar to that done by Murphey et al. (2006) for 19 June 2002. The combination of these high temporal and spatial resolution measurements provide a detailed account of the various preconvective features and their individual impacts on CI that occurred just east of the Oklahoma Panhandle on 12 June 2002.

\section{Overview of 12 June 2002}

\section{a. Synoptic discussion}

At 1200 UTC 12 June 2002 the IHOP_2002 domain was beneath a weak upper-level ridge that stretched from the desert Southwest to the Gulf of Mexico (not shown here; see Markowski et al. 2006). A vigorous upper-level low was centered over the northern Rockies and moved across the Canadian border by 0000 UTC 13 June 2002. A nearly stationary front extended across much of the United States, separating a tropical air mass to the south and a cooler, drier Canadian air mass to the north (Fig. 1). This stationary boundary extended through Nebraska, south through northwestern Kansas, and into southeastern Colorado. A meso- 

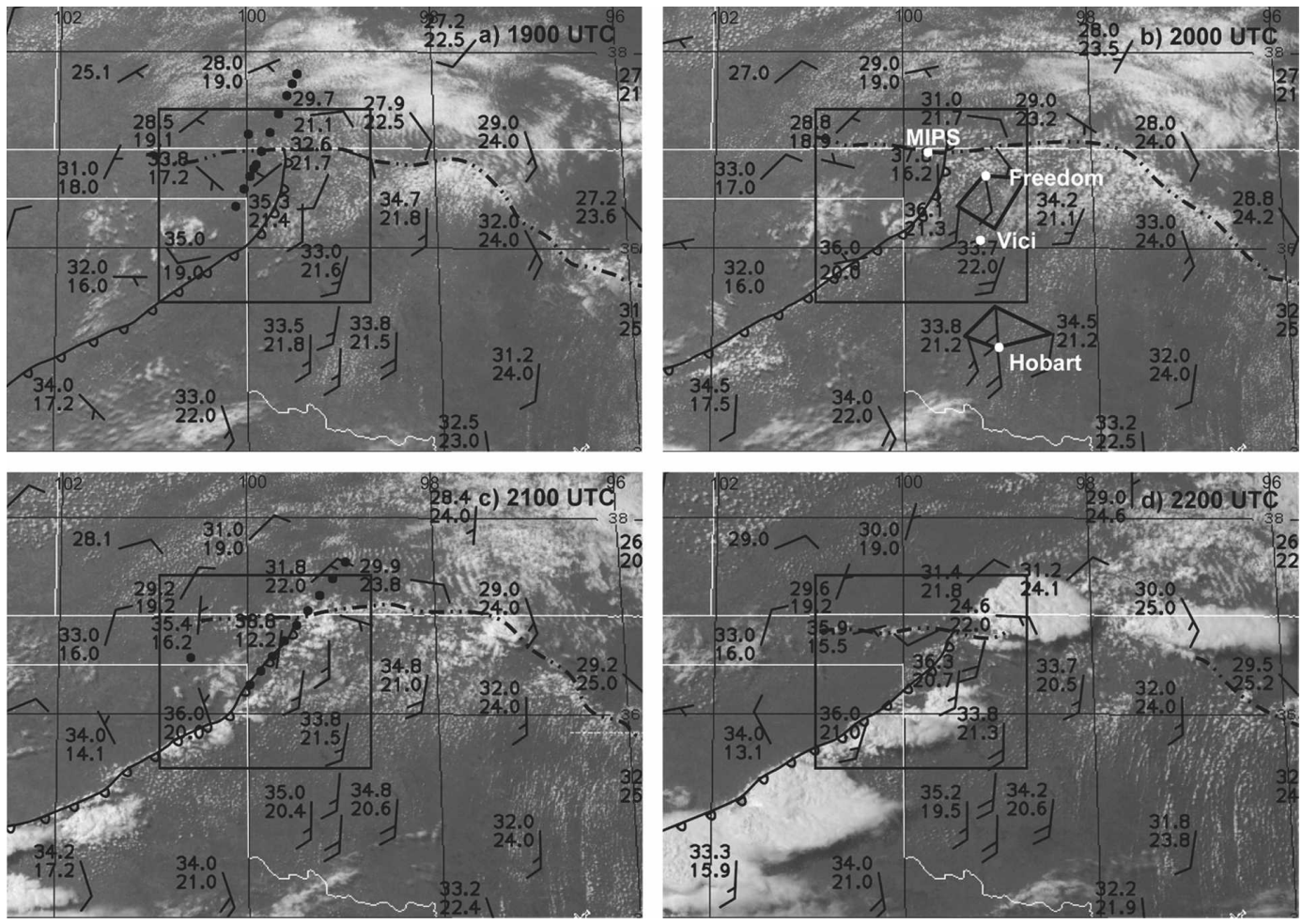

FIG. 2. Visible satellite imagery from (a) 1900, (b) 2000, (c) 2100, and (d) 2200 UTC 12 Jun 2002. Surface station measurements are plotted with temperature $\left({ }^{\circ} \mathrm{C}\right)$, dewpoint temperature $\left({ }^{\circ} \mathrm{C}\right)$, and winds with half-barb illustrating $5 \mathrm{~m} \mathrm{~s}^{-1}$ and a full barb illustrating $10 \mathrm{~m} \mathrm{~s}^{-1}$. Polygon regions used to calculate divergence shown in Fig. 6 are indicated in (b). Sounding locations (filled circles) used for creating plots in Figs. 4 and 5 are shown, respectively, in (a) and (c). Black box indicates composite reflectivity domain shown in Fig. 3. Approximate boundary locations discussed in the text are overlaid on the panels. Locations of sites discussed later are plotted in (b).

scale low pressure center developed near 1200 UTC over the Oklahoma Panhandle. An east-west boundary existed along the Oklahoma-Kansas border due to an outflow boundary from the previous evening's mesoscale convective systems. By 1800 UTC the east-west boundary propagated northward, showing some characteristics of a synoptic-scale warm front (e.g., Bluestein 1993). This northward propagation, however, may have been in response to the cyclonic circulation of the mesolow to the west. This east-west boundary will be referred to as an old outflow boundary (OB) throughout this paper. A dryline intersected the $O B$ just east of the mesolow and extended southwestward into the Texas Panhandle.

\section{b. Satellite, radar, and surface observations}

Hourly GOES-11 satellite and radar composites with surface station data overlaid are respectively presented in Figs. 2 and 3. At 1900 UTC the mesolow in the eastern Oklahoma Panhandle was readily apparent in the surface mesonet winds (Fig. 2a). Additionally, there was a suggestion of the mesolow circulation in the semi- circular outline of the cloud field to the north and northeast of the mesolow in south-central Kansas (Figs. $2 \mathrm{a}, \mathrm{b})$. The dryline zone location was estimated in Fig. 2a using the cloud field, moisture contrast, and wind direction. The northeast-southwest fine line indicating convergence associated with the dryline zone was apparent in Fig. 3a. The east-west OB zone was evident as a diffuse fine line in reflectivity along the OklahomaKansas border (Fig. 3a).

The surface winds still defined a subsynoptic low pressure region centered on the eastern edge of the Oklahoma Panhandle at 2000 UTC (Fig. 2b). The convergence associated with the dryline zone was apparent as a thin northeast-southwest-oriented cloud line with stronger surface moisture contrast across the zone. The east-west boundary along the Oklahoma-Kansas border showing the OB location was apparent in satellite imagery as a diffuse cloud line. This OB appeared to connect with a northwest-southeast-oriented outflow boundary in north-central Oklahoma. There was a suggestion of horizontal convective rolls in central Oklahoma, evident in the cloud streets oriented along the 

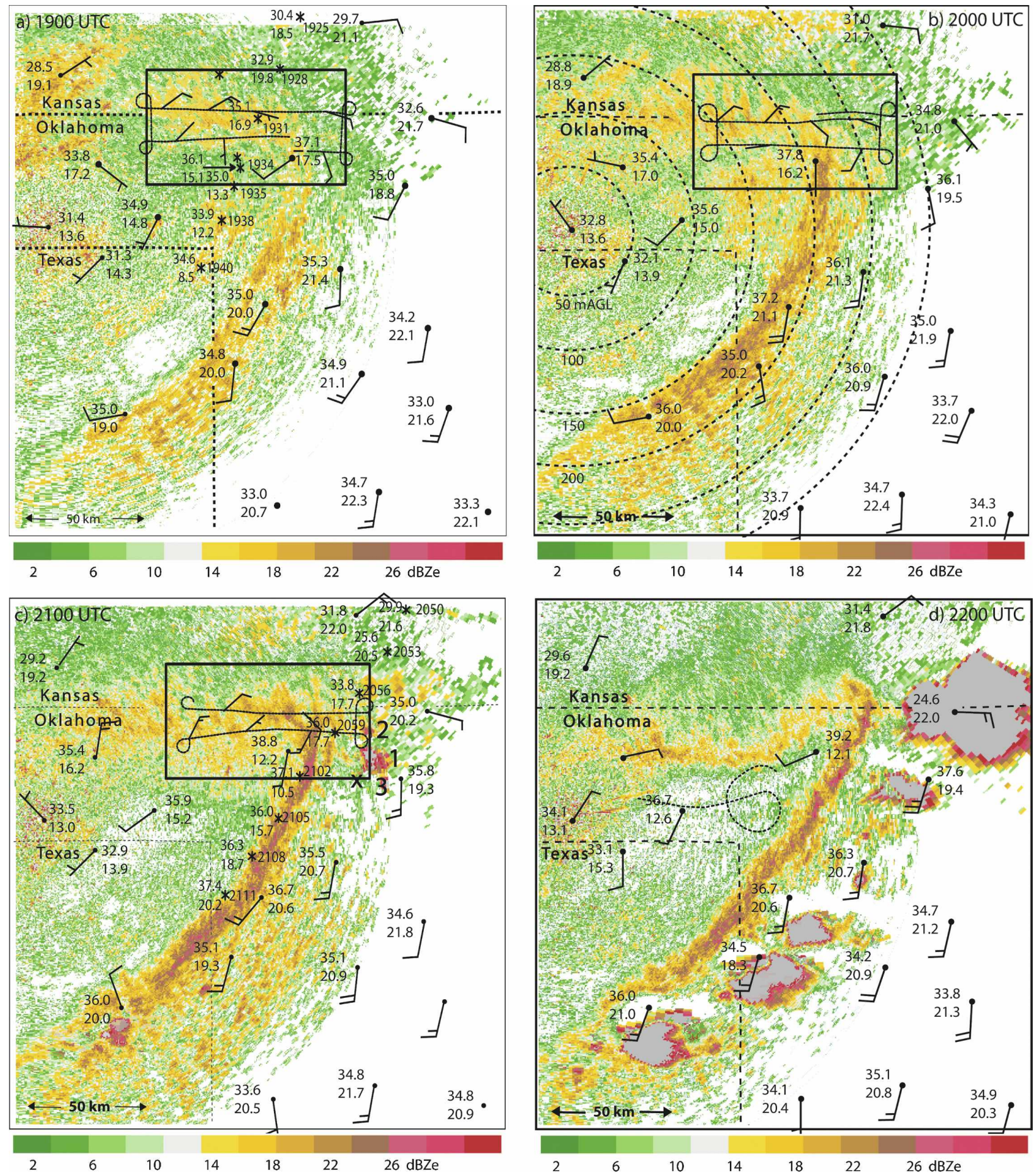

FIG. 3. Surface station data overlaid on low-level composite reflectivity fields for (a) 1900, (b) 2000, (c) 2100 , and (d) 2200 UTC 12 Jun 2002. The height of the radar data are shown in (b). Station plots show temperature on top $\left({ }^{\circ} \mathrm{C}\right)$ and dewpoint temperature on bottom $\left({ }^{\circ} \mathrm{C}\right)$, with a half-barb indicating $5 \mathrm{~m} \mathrm{~s}^{-1}$ and a full barb showing $10 \mathrm{~m} \mathrm{~s}^{-1}$. Surface dropsonde locations with surface temperature and dewpoint temperature are shown as asterisks in (a) and (c). Black box indicates ELDORA domain shown in Fig. 8. New cells, labeled 1 and 2 in (c), form at $\sim 2100$ UTC and merge together to form the northeastern supercell at 2200 UTC. The X labeled 3 in (c) indicates the location of a third echo forming at the same time but not yet apparent in the composite. 
low-level wind direction. North-south-banded structures, believed to be associated with internal gravity waves, were apparent in the radar composites (Fig. 3b), particularly within the western portion of the NRL P3 flight track. They were likely not cloud streets associated with horizontal convective rolls because they were oriented at a significant angle to the mean convective boundary layer (CBL) wind direction, the surface wind direction, and the inversion-level wind and shear directions, as required for rolls (e.g., Malkus and Riehl 1964; Brown 1972; LeMone 1973; Kelly 1984; Weckwerth et al. 1997).

Cloud bands, believed to be associated with internal gravity waves, were apparent in the 2100 UTC satellite imagery north of the OB (Fig. 2c). The radar reflectivity composite at 2100 UTC showed a more clearly defined convergence zone associated with the triple point, or intersection, between the three air masses: (i) easterly cool, moist flow north of the OB, (ii) southerly warm, moist flow east of the dryline, and (iii) southwesterly hot, dry flow west of the dryline (Figs. 2c and $3 c)$. Note the more extensive coverage of cloud streets (i.e., horizontal convective rolls) covering much of Oklahoma southeast of the triple point at 2100 UTC (Fig. 2c). The linear reflectivity elements just east of the dryline zone and triple-point region provided further evidence of rolls in the region (Figs. 3b,c).

Three individual convective cells formed $\sim 20 \mathrm{~km}$ from the triple point at $\sim 2100$ UTC (Fig. 3c). The southern cell dissipated in $\sim 20 \mathrm{~min}$ while the two northern cells (labeled 1 and 2) merged to form a supercell that produced hail and damaging winds in southern Kansas (Figs. 2d and 3d). The convection farther away from the triple point extending southward along the dryline formed when clouds advected eastward over the dryline. The clouds may have illustrated low- and midlevel moisture advection and provided extra forcing within the moist cloud layers that led to deep convection in that region. The Advanced Regional Prediction System (ARPS) numerical model has successfully simulated most of the complicated CI structure across the IHOP_2002 domain on 12 June 2002 (Liu and Xue 2008). This current study focuses on the convection that initiated near the triple point where the high-resolution observations were obtained.

\section{c. Soundings and wind profilers}

Data from two dropsonde legs nearly normal to the OB were obtained. The first leg (1918:56-1940:53 UTC) had nearby mobile sounding ascents near the dropsonde times (for locations, see Figs. 2a and 3a) and were therefore included in the dropsonde composite figure (Fig. 4). The relatively cool, moist air within the low-level easterly flow north of the OB was apparent. This air exhibited a relatively lower CBL depth [base of strong gradient in potential temperature, at $817 \mathrm{mb}$ $(\sim 1.2 \mathrm{~km} \mathrm{AGL})]$ as compared with the hot, dry air south of the OB and west of the dryline [drops at 1935, 1938, and 1940 UTC; $731 \mathrm{mb}(\sim 2.1 \mathrm{~km}$ AGL)]. There is a suggestion of the dropsonde leg crossing the dryline between the 1934 and 1935 UTC drops due to the deep virtual potential temperature plume at the center of the broad-scale convergence, as shown in previous dryline studies (e.g., Ziegler et al. 1997).

The convective available potential energy (CAPE; Fig. 4b), convective inhibition (CIN; Fig. 4b), LFC (Fig. 4a), and lifted index (LI; Fig. 4b) were calculated using the lowest-50-mb averaged virtual potential temperature-based parcel calculations (e.g., Doswell and Rasmussen 1994; Ziegler et al. 1997). Note that the dropsonde CAPE values were underestimates because the dropsondes were released from flight level at $445 \mathrm{mb}$ ( $\sim 6 \mathrm{~km}$ AGL). Thus, they represented only the partial CAPE values, not the total CAPE throughout the entire depth of the troposphere. The CIN and LI values were not affected by this vertical cutoff because all of the CIN in the sounding is below $6 \mathrm{~km}$ and LI was determined at $500 \mathrm{mb}$. In a relative sense, the most unstable region sampled by the dropsondes and radiosondes was near the OB (indicated by the black-shaded section on the $x$ axis). This region exhibited the lowest values of CIN, LI, and LFC, and the highest partial CAPE values.

The second dropsonde leg commenced approximately 90 min after the first (2047:38-2111:38 UTC), and several drops were released along the mean dryline location and near the CI time and location (surface drop locations are shown in Figs. 2c and 3c) but unfortunately not in the pure CI air mass. While the air mass north of the $\mathrm{OB}$ warmed and moistened due to daytime heating and moisture advection from the east, respectively, the low-level winds remained easterly (Fig. 5a). The CBL depth was slightly lower than the earlier dropsonde leg [837 mb ( 1.0 km AGL)]. This dropsonde leg included one drop (2059 UTC) that was near the triple point that was dropped near the time and location of CI (indicated by an arrow at the bottom of Fig. 5b). This drop was the closest to the CI location but did not sample the pure CI air mass away from the boundaries. The air mass near the triple point exhibited the deepest moist layer of these two sounding composites. The four southern drops were released along the mean position of the dryline with the 2102 UTC drop on the western edge of the dryline zone, and the 2105 , 2108 , and 2111 UTC drops on the eastern edge of the dryline convergence zone. The 2102 UTC drop on the 

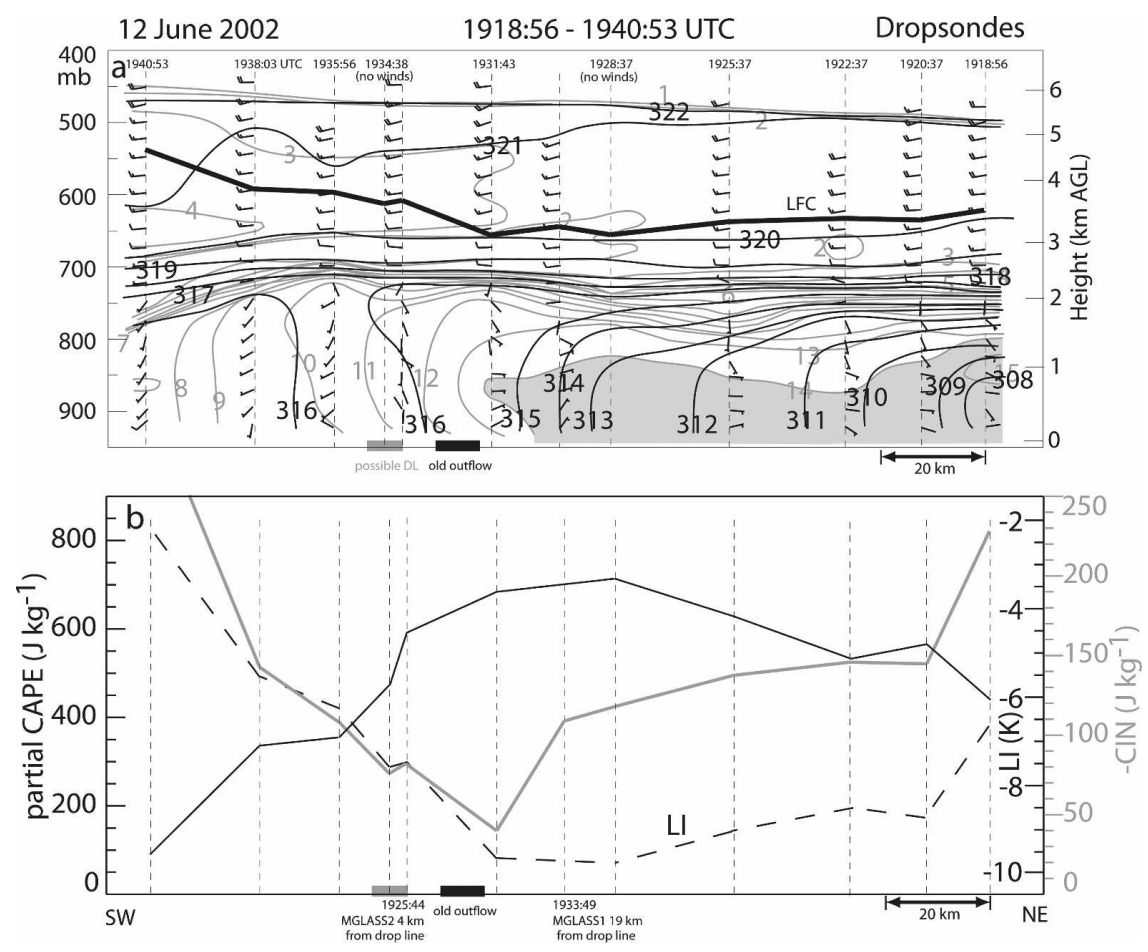

FIG. 4. First dropsonde leg from 1918:56 to 1940:53 UTC 12 Jun 2002. Surface sounding locations are shown in Figs. 2a and 3a. (a) Virtual potential temperature (K; black contours), mixing ratio ( $\mathrm{g} \mathrm{kg}^{-1}$; gray contours; values $>14 \mathrm{~g} \mathrm{~kg}^{-1}$ are shaded), and LFC (km AGL; thick black line) are plotted. Winds are shown with half barbs for $2.5 \mathrm{~m} \mathrm{~s}^{-1}$ and full barbs for 5 $\mathrm{m} \mathrm{s}^{-1}$. (b) Partial CAPE ( $\mathrm{J} \mathrm{kg}^{-1}$; solid black line) calculated up to flight level [ $\sim 445 \mathrm{mb}(\sim 6.5$ $\mathrm{km})$ ], CIN ( $\mathrm{J} \mathrm{kg}^{-1}$; gray), and LI (K; dashed black line) values are shown. Two MGLASS ground-based sounding launches are added to this composite because they were near the dropsonde line in space and time. The region nearest the OB reflectivity fine line is shaded black on the bottom. The possible dryline location is also shown with gray shading at the bottom of both (a) and (b).

west of the dryline zone was again dry and hot with a deeper CBL [698 mb ( 2.5 km AGL)], and the southwesterly flow persisted. The three southern drops near the dryline convergence zone sampled moist CBL air (drops at 2105, 2108, and 2111 UTC). This moist region along the dryline convergence zone may have been caused by advection of a moist air mass shown in visible satellite imagery as a cluster of small cumulus clouds propagating eastward through the region (not shown). More likely, however, is that the dropsondes were released along the mean dryline position, sampling both sides of the dryline region. The three moist drops toward the southwest were likely sampling the region on the eastern edge of the dryline zone.

Note the strong boundary layer deep convergence between drops 2056 and 2059 UTC, suggesting a greater propensity for $\mathrm{CI}$ in the triple-point region. Additionally, the CAPE-CIN-LI composite (Fig. 5b) and LFC estimates (Fig. 5a) for the second dropsonde leg showed again that the most unstable region, with the lowest CIN, LI, and LFC and highest partial CAPE, occurred near the triple point. An examination of the evolution of approximately collocated soundings suggested that vertical mixing destroyed the capping inversion layer and destabilized the environment both north and south of the $\mathrm{OB}$ and west of the dryline (not shown).

\section{Preconvective features}

While the thermodynamics, winds, and boundaries were conducive to storm development on 12 June, this information alone did not address the location or timing of the first convective cells. To address this issue, a discussion of each of the preconvective features will be presented.

\section{a. Mesolow}

The mesoscale low pressure center was readily apparent in the surface pressure (Fig. 1) and wind fields (e.g., Fig. 2) and in the cloud and radar movie loops. 

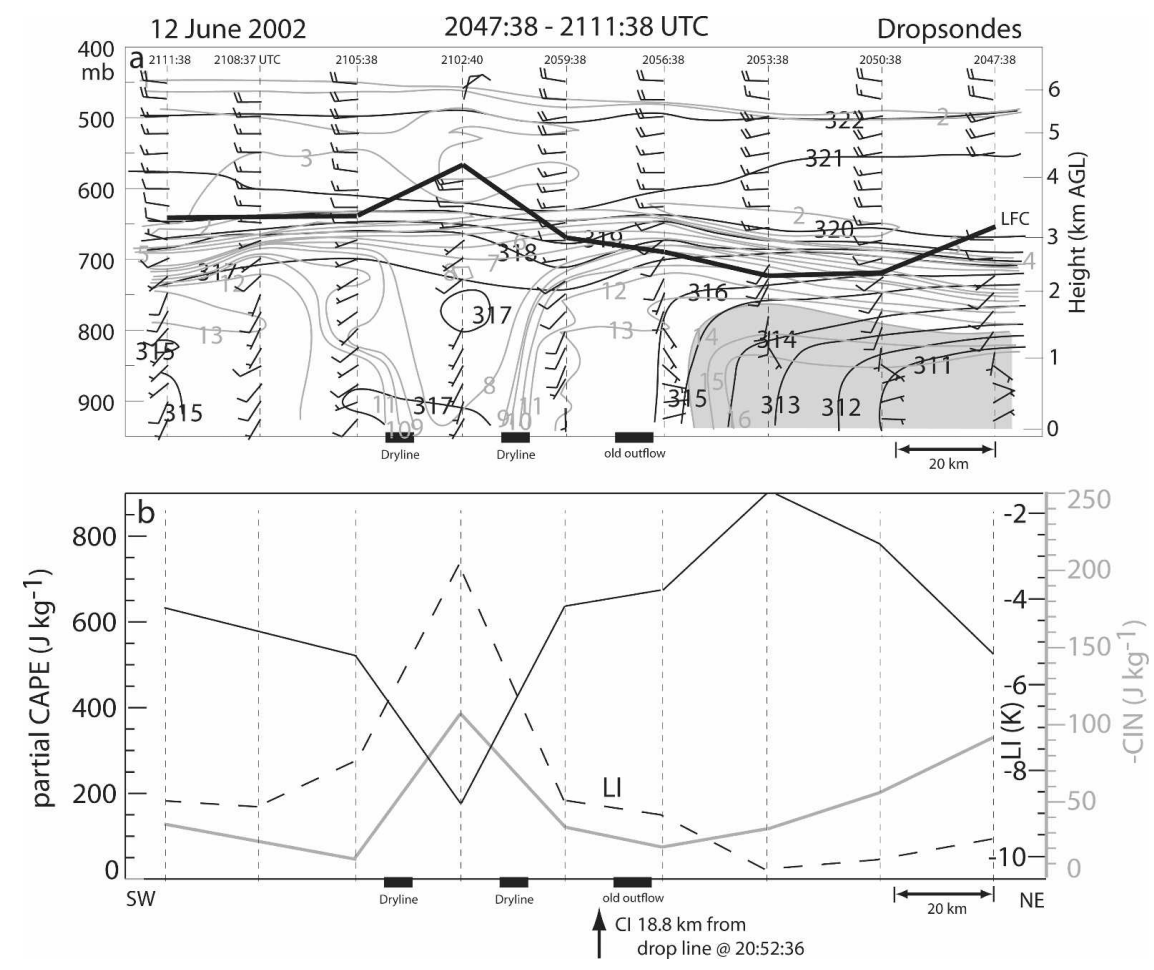

FIG. 5. As in Fig. 4, but for dropsonde leg 2 from 2047:38 to 2111:38 UTC 12 Jun 2002. Surface dropsonde locations are shown in Figs. 2c and 3c. The CI location nearest the dropsonde location and time is indicated with arrow at bottom.

This mesolow was observed early in the morning $(\sim 1200$ UTC) and was persistent throughout the preconvective time period. Figure 6 illustrates the potential impact of the mesolow, which was evaluated by contrasting data averaged from Oklahoma Mesonet stations in two regions-one polygon near Freedom, Oklahoma, near the CI region, and one polygon farther south near Hobart, Oklahoma, in a region not affected by the mesolow (see Fig. $2 b$ for station and polygon locations).

In the CI polygon toward the north, the strength of the southerly flow (Fig. 6a) increased approximately $2 \mathrm{~h}$ prior to CI. In addition, there was a fairly constant increase in surface moisture content until 1800 UTC, when it dropped slightly and remained constant thereafter. The drop in moisture and gradual wind shift at 1810 UTC was due to the OB propagating northward past the Freedom region (Fig. 6b). In contrast, farther to the south, the strength of the wind, while also southerly, did not increase as dramatically throughout the time period (Fig. 6a). Furthermore the moisture in the south slightly decreased due to diurnal mixing (Fig. 6b).

Divergence within the polygons of Fig. $2 \mathrm{~b}$ was calculated using the finite version of the divergence theorem (e.g., Johnson and Priegnitz 1981; Holton 2004),

$$
\boldsymbol{\nabla} \cdot \mathbf{v}=A^{-1} \oint v_{n} d s,
$$

where $A$ is the area of the polygon region and $v_{n}$ represents the component of wind normal to each side of the perimeter of the polygon. The length of each side of the polygon is given by $d s$. The convergence (Fig. 6b) actually decreased in the Freedom CI region $\sim 3 \mathrm{~h}$ prior to $\mathrm{CI}$ and became slightly divergent $\sim 1 \mathrm{~h}$ before $\mathrm{CI}$. The divergence toward the south remained near zero throughout the time period.

The mesolow caused surface divergence in the CI region prior to $\mathrm{CI}$; thus, its impact on the surface convergence field was not supportive of CI. It did appear, however, that the mesolow enhanced the southerly, moist flow into the $\mathrm{CI}$ region.

\section{b. Dryline}

The dryline is well known for its association with CI (e.g., Rhea 1966; Bluestein et al. 1988; Bluestein and Parker 1993; Hane et al. 1993; Ziegler et al. 1997; Ziegler and Rasmussen 1998; Hane et al. 1997; Hane et al. 2001; Hane et al. 2002). In fact the first dryline clouds and storms often form up to $25 \mathrm{~km}$ from the surface dryline location (e.g., Rhea 1966; Ziegler and Rasmus- 

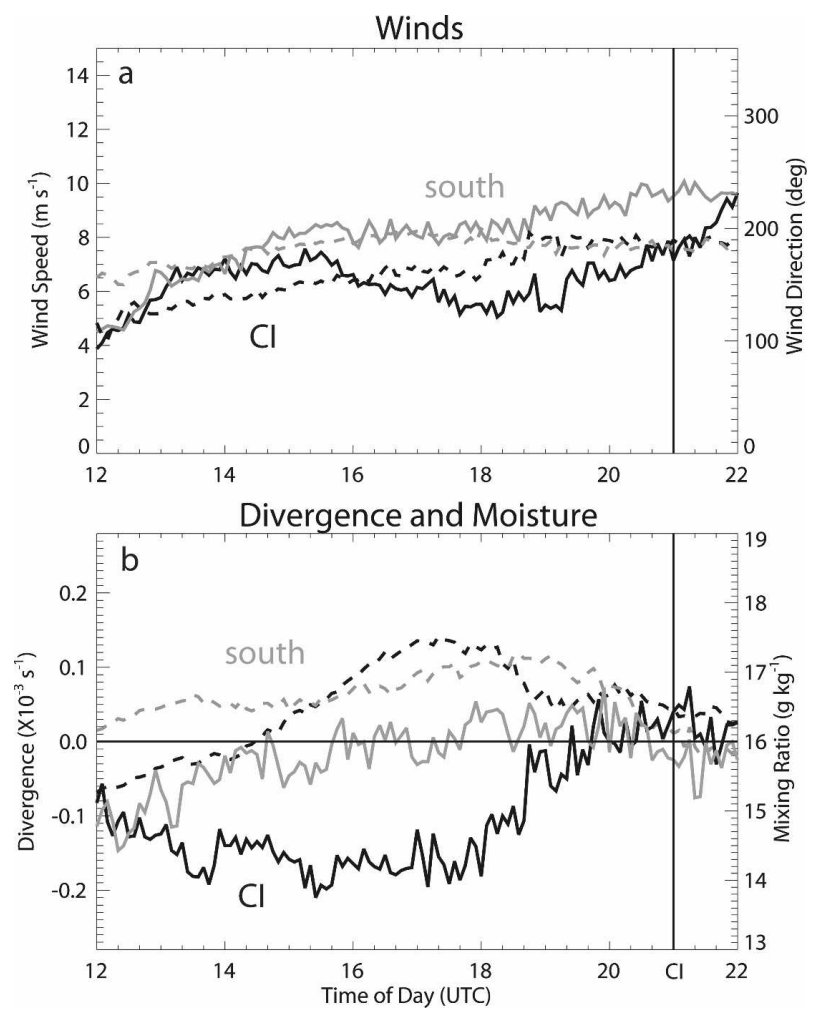

FIG. 6. The 12 Jun 2002 surface station time series averaged within polygons shown in Fig. $1 \mathrm{~b}$ for the northern CI region (black lines) and southern region (gray lines), illustrating (a) wind speed $\left(\mathrm{m} \mathrm{s}^{-1}\right.$; solid lines) and direction ( ${ }^{\circ}$; dashed lines), and (b) divergence $\left(\times 10^{-3} \mathrm{~s}^{-1}\right.$, solid lines) and mixing ratio $\left(\mathrm{g} \mathrm{kg}^{-1}\right.$; dashed lines). Vertical line indicates time of CI. Divergence was also calculated within polygons shown in Fig. 1b. Negative values indicate convergence.

sen 1998; Wilson and Roberts 2006), and there is increasing evidence that the cloud-scale details of the 3D stability and wind fields dictate where cumulus clouds and CI develops (e.g., Ziegler et al. 2007). The convergence associated with the dryline zone on 12 June 2002 was well defined in the cloud field and radar composites by 2000 UTC (Figs. 2b and 3b). The dryline zone exhibited a broad $5^{\circ}-8^{\circ} \mathrm{C}$ surface dewpoint temperature drop. The dryline was imbedded within a broad surface deformation field, that is, southerlies east of and southwesterlies west of the dryline (Figs. 3a,b).

The first dropsonde leg shows a suggestion of crossing the dryline between the 1934 and 1935 UTC drops. Note the broad moisture gradient and larger-scale wind shift and the deeper virtual potential temperature contours, as seen in previous dryline studies (e.g., Ziegler et al. 1997). NRL P3 in situ measurements crossing the dryline convergence zone very near the triple point from 1916 to 1926 UTC at $\sim 330 \mathrm{~m}$ AGL showed a $0.07 \mathrm{~K} \mathrm{~km}^{-1}$ gradient in potential temperature and a
$0.3 \mathrm{~g} \mathrm{~kg}^{-1} \mathrm{~km}^{-1}$ gradient in mixing ratio (Fig. 7b). While the moisture gradient across the convergence zone was apparent, the air on the west side of the flight track was not dry enough to be pure dryline air. Thus, it is believed that the P3 was actually flying within the $\mathrm{OB}$ and thereby sampled higher moisture values than it would have observed farther south. The strongest in situ upward vertical velocity measurements of 2-3 $\mathrm{m} \mathrm{s}^{-1}$ occurred within the boundary layer convection regions away from the radar reflectivity fine lines depicting the mesoscale convergence zones (Fig. 7c). This lack of significant updraft enhancements along the mesoscale boundaries compared with those resulting from boundary layer convection was also illustrated in multiDoppler radar retrievals by Markowski et al. (2006).

During the subsequent NRL P3 leg in the same region, from 2028 to 2038 UTC (Figs. 7f,g), the radar fine line associated with the dryline zone was more well defined and intense (cf. Figs. 7a,f), and the thermodynamic gradients sampled by the NRL P3 increased (i.e., $0.08 \mathrm{~K} \mathrm{~km}^{-1}$ and $0.5 \mathrm{~g} \mathrm{~kg}^{-1} \mathrm{~km}^{-1}$ ). Again the air on the west side of the north-south fine line was not dry enough to be pure dryline air; thus, it is believed that the P3 was flying within the $\mathrm{OB}$ zone. The upward vertical velocities within the fine line were slightly stronger $\left(1.5 \mathrm{~m} \mathrm{~s}^{-1}\right)$, broader, and more sustained at this time, but were still of a comparable magnitude to the updrafts associated with the surrounding boundary layer convection (Fig. 7h).

It appears that the second dropsonde leg (Fig. 5) sampled air along the mean dryline position. The drop at 2059 UTC was east of the dryline location, sampling relatively cool, moist boundary layer air. The 2102 UTC drop descended on the western edge of the dryline zone, sampling relatively warm, dry boundary layer air. The 2105, 2108, and 2111 UTC drops appeared to again be on the east side of the dryline zone, each sampling relatively cool, moist boundary layer air. The location of the drops relative to the reflectivity fine line (Fig. 3c) and the CBL southwesterly flow sampled by these dropsondes (Fig. 5a) suggests a wide mixing zone with the primary convergence on the eastern edge of the dryline zone. Buban et al. (2007) also showed that the 22 May 2002 dryline location during IHOP_2002 corresponded with the western edge of the radar reflectivity fine line. These observations suggest a horizontal wave-like structure along the dryline zone; similar undulations along the dryline have been observed by Koch and McCarthy (1982) and Buban et al. (2007).

These observations suggested a strengthening dryline zone with greater convergence and stronger thermodynamic gradients prior to CI. This was supported by maps of virtual potential temperature (not shown), in- 
1920
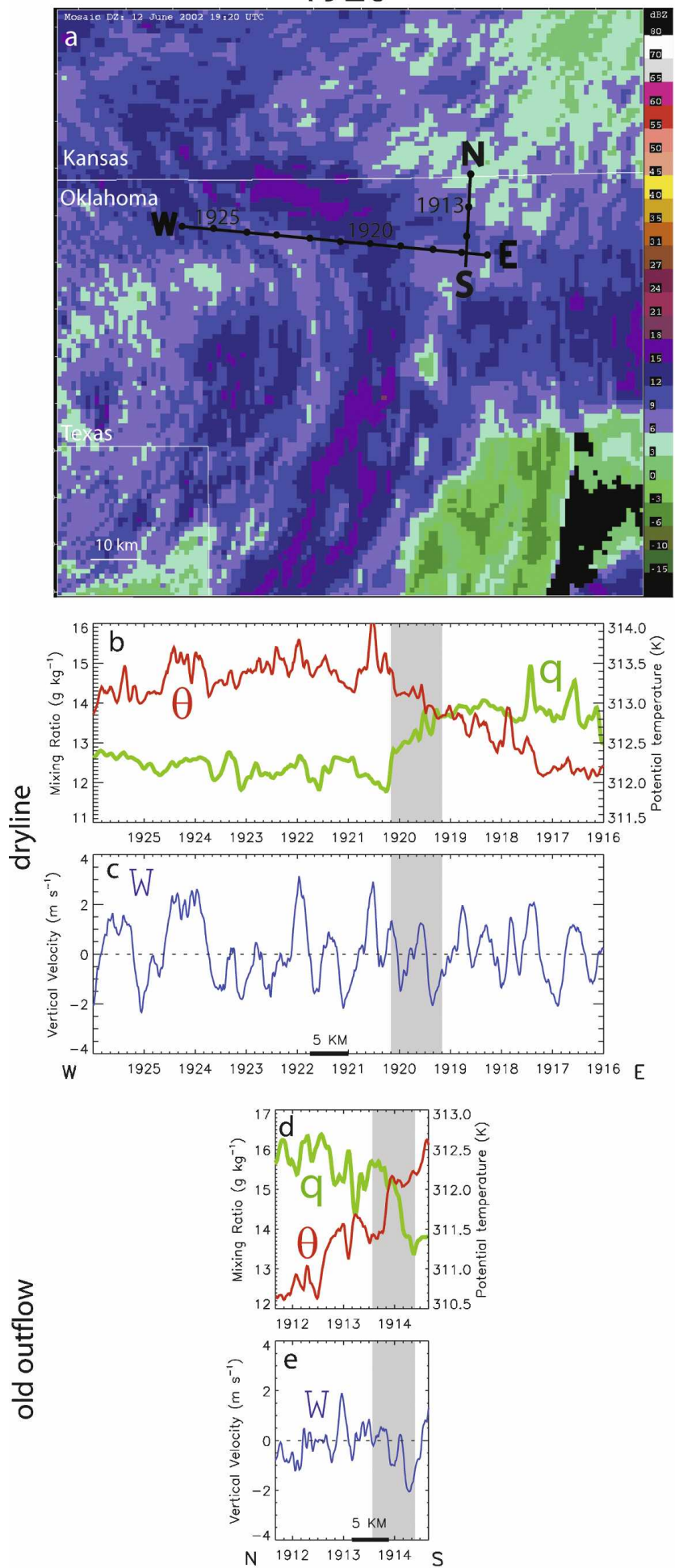

2030
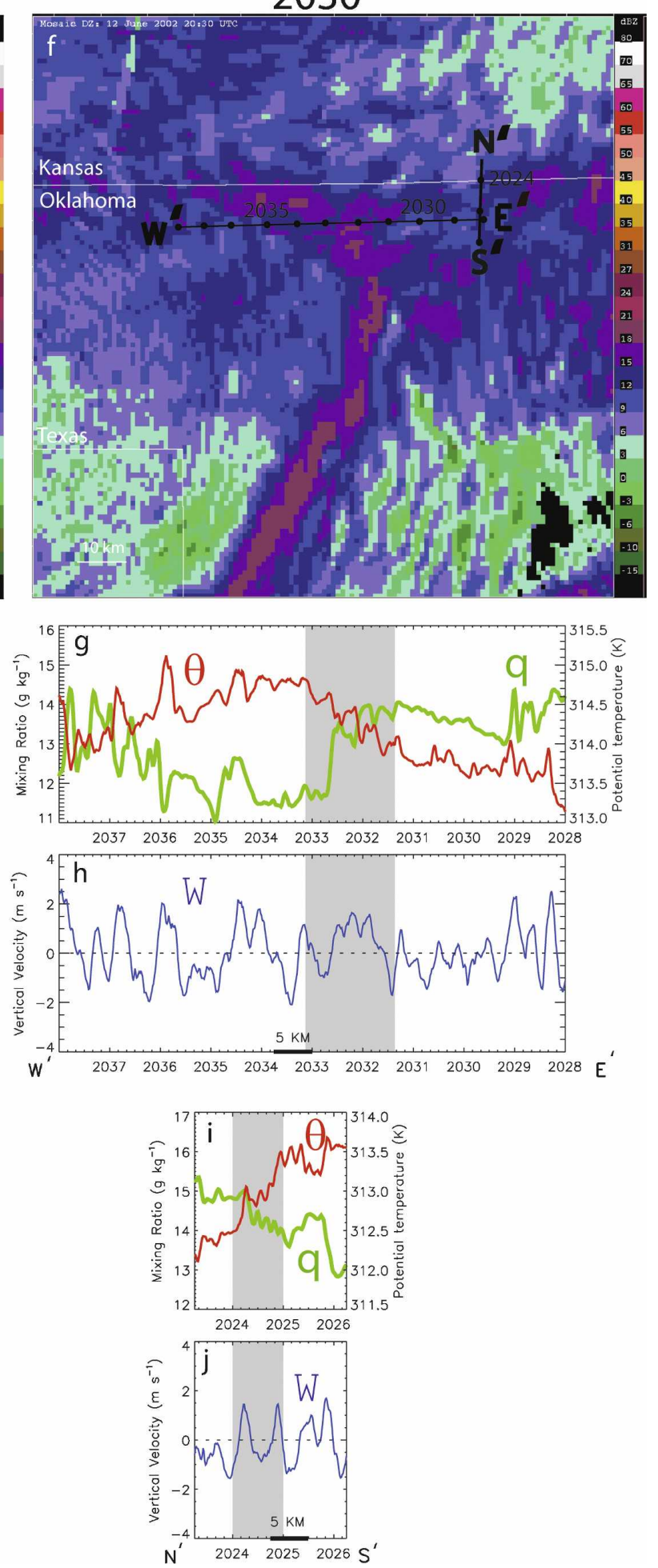

FIG. 7. (top) Composite reflectivity field at (a) 1920 and (f) 2030 UTC 12 Jun with NRL P3 flight tracks overlaid. The corresponding NRL P3 in situ potential temperature (K; red), mixing ratio $\left(\mathrm{g} \mathrm{kg}^{-1}\right.$; green), and 10 -s mean vertical velocity (m s${ }^{-1}$; blue) for (b), (c), (g), (h) the dryline zone and (d), (e), (i), (j) the OB zone from $\sim 330 \mathrm{~m}$ AGL are shown beneath each corresponding radar panel. Shaded sections indicate radar fine-line regions. 
dicating increasing maxima along and east of the dryline. As indicated by the more well-defined fine line associated with the dryline convergence zone and the strengthening gradients across the dryline-triple-point region, the dryline appeared to be causing a broad increase in convergence in the CI region. Because it is necessary to have organized mesoscale updrafts to lift parcels to the lifting condensation level (LCL) and LFC, drylines are optimal locations for CI (e.g., Ziegler and Rasmussen, 1998).

\section{c. Old outflow boundary}

Two mesoscale convective systems from the previous evening produced an east-west outflow boundary that stalled along the Oklahoma-Kansas border near the region of interest. During the daytime hours of 12 June 2002, the OB strengthened and was apparent as a wind shift and exhibited slightly cooler and moister air toward the north (e.g., Figs. 2a and 3a). Starting in northcentral Oklahoma, a northwest-southeast extension of the OB continued into eastern Oklahoma. Convection initiated near the intersection of the east-west old outflow boundary segment with the northwest-southeast segment. This region of limited IHOP_2002 measurements, however, is not the focus of this paper.

By 1810 UTC the OB in the CI region started to propagate slowly northward. This northward propagation was apparent in the wind shift and moisture decrease measured at the Freedom surface station (Fig. 6 ). Additionally, there was some evidence of a surface pressure field perturbation (Fig. 1), indicating that the boundary had significantly altered the mass field, showing some characteristics of a warm front as it continued to drift slowly northward until $\sim 2000$ UTC.

The OB reflectivity fine line was not as well defined as the fine line associated with the dryline convergence zone. Figures $7 \mathrm{a}$,f show a broad, diffuse east-west reflectivity fine line. This may have been due to weaker convergence and less sustained updrafts associated with the OB zone. During the short southward NRL P3 leg from 1911:40 to 1914:40 UTC the potential temperature and mixing ratio gradients were, respectively, $0.15 \mathrm{~K}$ $\mathrm{km}^{-1}$ and $0.215 \mathrm{~g} \mathrm{~kg}^{-1} \mathrm{~km}^{-1}$ (Fig. 7d). The subsequent flight pass at 2023:15-2026:15 UTC sampled weaker gradients of potential temperature $\left(0.098 \mathrm{~K} \mathrm{~km}^{-1}\right)$ and mixing ratio $\left(0.16 \mathrm{~g} \mathrm{~kg}^{-1} \mathrm{~km}^{-1}\right.$; Fig. 7i). Unfortunately the P3 leg did not extend far enough south to sample the complete OB zone, but the mesoscale thermodynamic gradients across a segment of the OB zone were nearly constant (cf. Figs. 4 and 5).

The in situ observations suggested stronger, more sustained vertical velocities at the later time (cf. Figs. $7 \mathrm{e}, \mathrm{j}$ ). Indeed, the dropsondes straddling the OB (drops at 2056:38 and 2059:38 UTC) with their low-level easterly and southwesterly flow, respectively, indicated convergence throughout the depth of the CBL. In fact, the convergence estimated across the old outflow was $\sim 2.5 \times 10^{-4} \mathrm{~s}^{-1}$. Using a layer average of half of this value over the CBL depth of $\sim 2 \mathrm{~km}$, a peak mesoscale updraft of $\sim 0.25 \mathrm{~m} \mathrm{~s}^{-1}$ was possible. This may have been relevant to CI because the northeastward upward slope of the CBL between the 2056 and 2059 UTC drops was $\sim 0.5 \mathrm{~km}$ per $20 \mathrm{~km}$. With the southerly flow of $\sim 5 \mathrm{~m} \mathrm{~s}^{-1}$, this implied a mesoscale updraft of $\sim 0.125$ $\mathrm{m} \mathrm{s}^{-1}$ to create this slope by passive scalar advection. Because this estimated vertical velocity was near the expected maximum value, it is reasonable. It was possible that the mesoscale updraft penetrated somewhat higher than the CBL top and may have been a contributor to CI. At the minimum, the combined mesoscale convergence associated with the $\mathrm{OB}$ and the dryline appeared to cause a broad increase in $\mathrm{CBL}$ horizontal convergence in the CI region.

\section{d. Triple point}

The intersection between boundaries has long been known to be a primary location for new convective development (e.g., Purdom and Marcus 1982). In particular, the triple point, or the intersection between a dryline with either a cold front or outflow boundary, has been shown to focus convection initiation (e.g., Bluestein et al. 1990; Wakimoto et al. 2006). For this reason the triple point between the dryline and $\mathrm{OB}$ was targeted for mobile CI operations on 12 June 2002. From the beginning of the operational period until $\sim 1900$ UTC, the triple-point location was not apparent because of the active boundary layer convection creating highly populated cloud fields and poorly defined mesoscale radar fine lines (Figs. 2, 3, and 7). Unfortunately, this led to the mobile ground-based systems being positioned too far to the west and unable to sample the triple-point and CI region (Markowski et al. 2006). After 1900 UTC, the NRL P3 with ELDORA and LEANDRE II identified the triple point and collected an excellent time series on its evolution prior to CI (Fig. 8).

A sequence of pseudo-dual-Doppler analyses from ELDORA show a broad and fragmented OB (Fig. 8a) and a suggestion of a better-defined dryline extending southward in several of the passes (Figs. 8b,c). The P3 flight-level winds are overlaid along the flight track in Fig. 8. There was generally good agreement between ELDORA and NRL P3 flight-level winds in Fig. 8, but Fig. 8a showed some discrepancies. These discrepancies were likely caused by a number of factors, as follows: (i) Instantaneous in situ winds were plotted and there was 
a) $1855: 35-1908: 30$ UTC

$700 \mathrm{~m}$ AGL

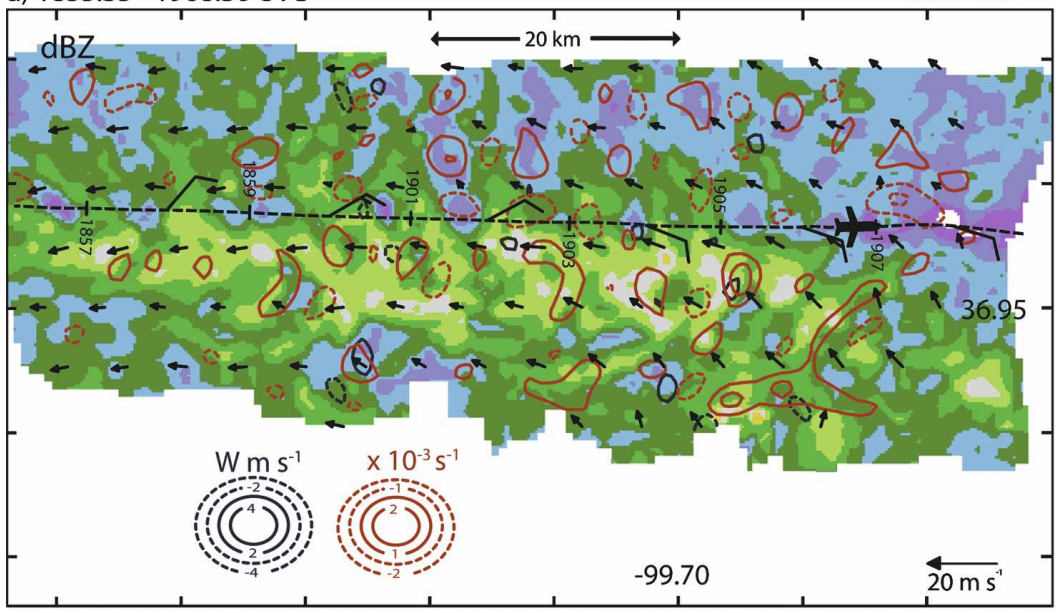

b) 1951:30-2002:25 UTC 700m AGL

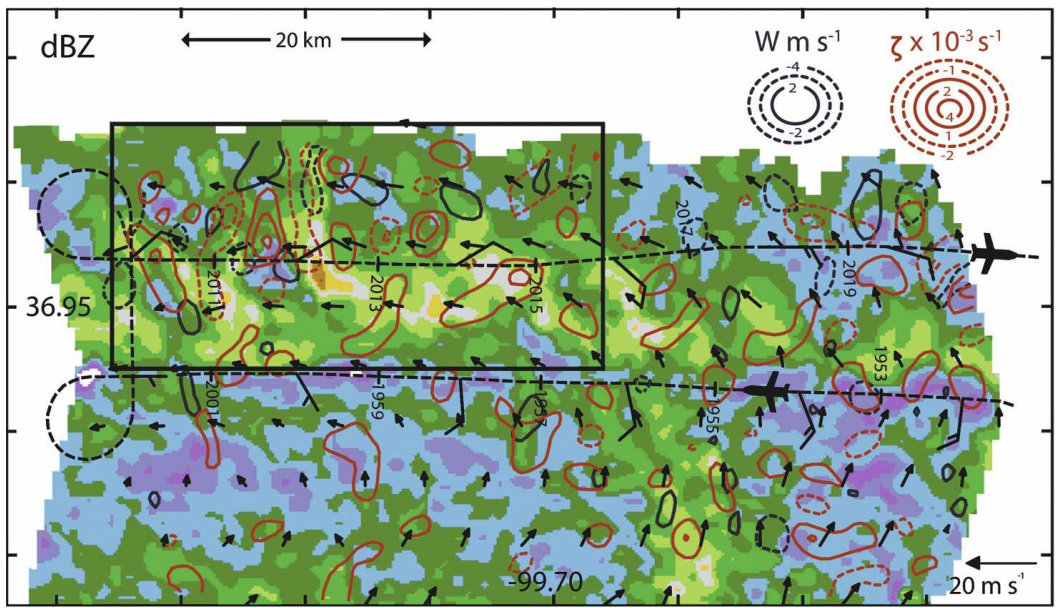

C) 2102:00 - 2112:50 UTC

$700 \mathrm{~m}$ AGL

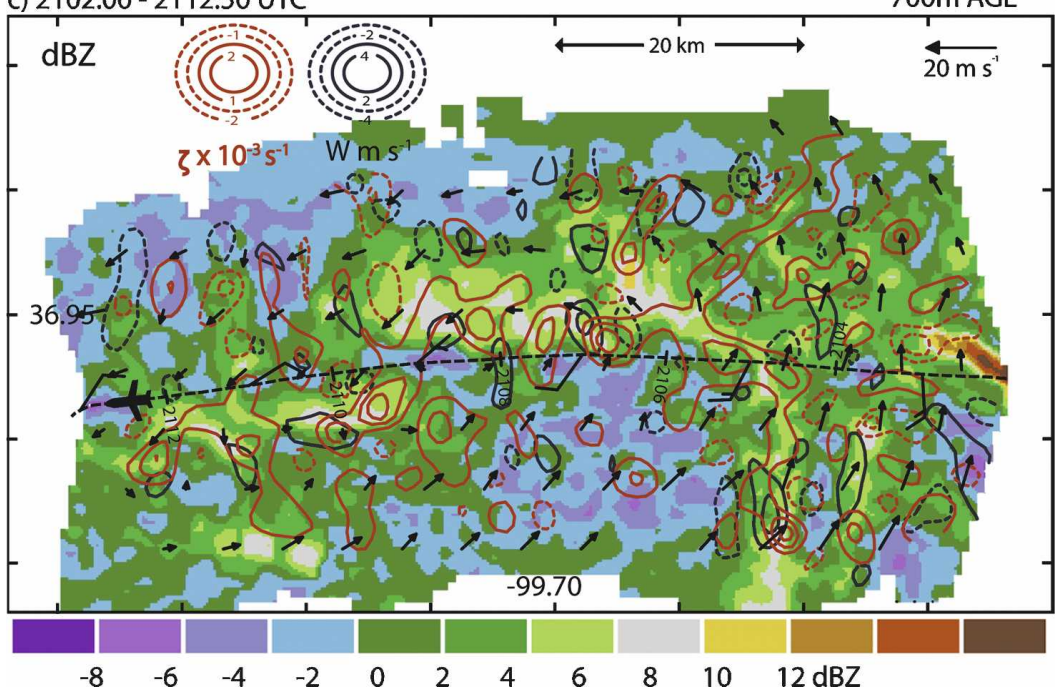

FIG. 8. Time sequence of ELDORA radar reflectivity (color shading), derived vertical velocity (blue contours; $\mathrm{m} \mathrm{s}^{-1}$ ), and vertical vorticity (red contours; $\times 10^{-3} \mathrm{~s}^{-1}$ ) at (a) 1855, (b) 1951, and (c) 2102 UTC. Region shown is indicated as a box in Fig. 3. Flight tracks and in situ winds are indicated in each panel. Box of (b) will be shown in Fig. 10. 


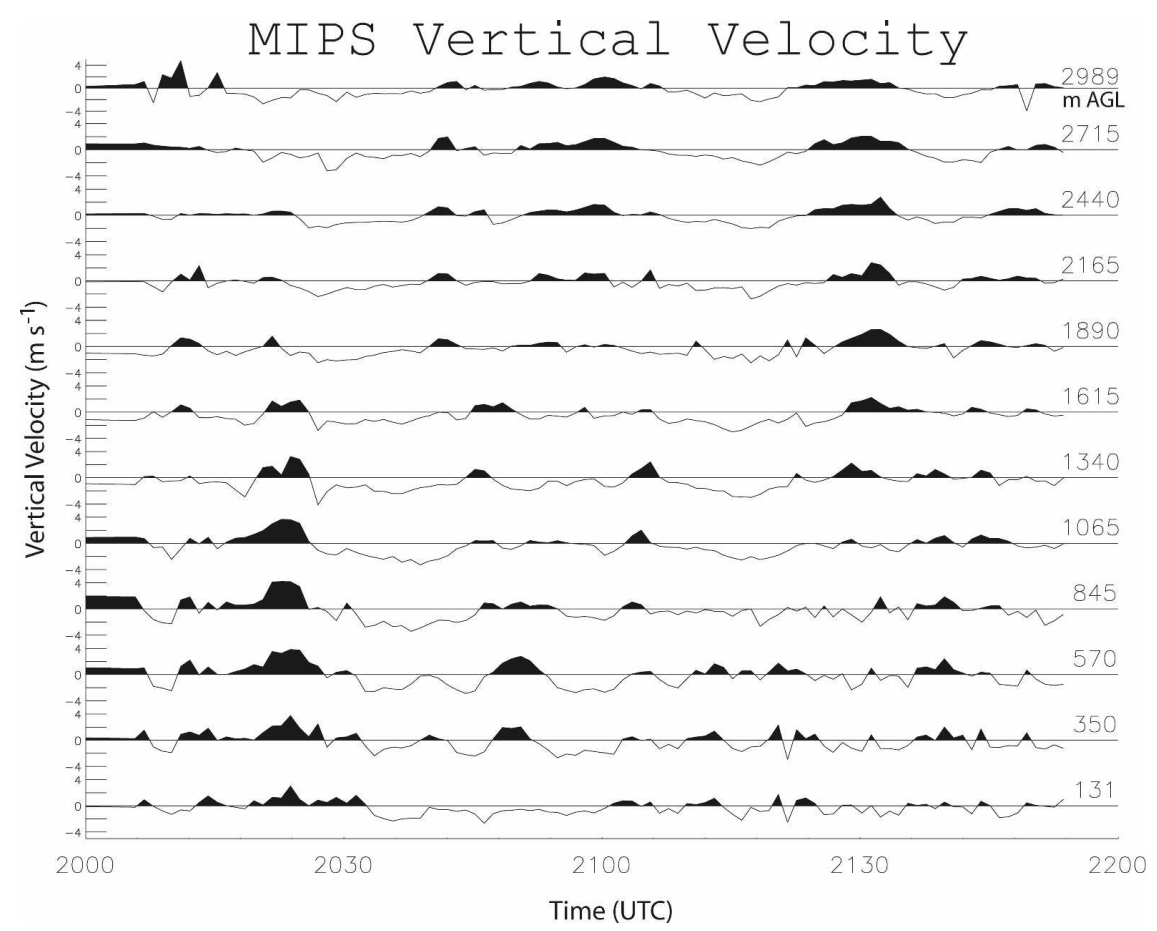

FIG. 9. Time series of MIPS vertical velocity $\left(\mathrm{m} \mathrm{s}^{-1}\right)$ from 2000 to 2200 UTC 12 Jun 2002 at several heights (m AGL), as indicated for each level. MIPS location is shown in Fig. $2 b$.

a high degree of variability in those high-resolution observations. (ii) Because the flight level was within the turbulent $\mathrm{CBL}$, the flight level was highly variable (460-680 m AGL). (iii) The navigational corrections (e.g., Lee et al. 1994) were performed to minimize the errors along the entire track and were not performed for each individual sweep. Thus, discrepancies between the flight-level winds and the ELDORA winds are expected.

Similar to that observed by Markowski et al. (2006) farther to the west on this day, the vertical velocity field was weak and unorganized. In fact, the magnitude of the updrafts in the boundary layer thermals and horizontal convective rolls was comparable to those measured within the mesoscale boundaries. This was consistent with the in situ observations discussed with Fig. 7. Both the vertical velocity and vertical vorticity fields showed increasing values throughout the sequence of Fig. 8. Near the time of CI (Fig. 8c), the fine-line reflectivity intensity near the triple point had increased and the vertical velocities in the region were slightly stronger but remained rather weak and unorganized. This was consistent with a well-populated cumulus field shown in the satellite imagery (Fig. 2c).

As mentioned in the previous two sections, the convergence along the dryline and $\mathrm{OB}$ was increasing prior to CI. Additionally, the triple-point convergence, as in- dicated by the clear-air reflectivity values, was also increasing. There was an increase in the depth of the moisture in dropsonde 2059 UTC (Fig. 5a) where the reflectivity enhancement was collocated, suggesting locally enhanced vertical motion near the OB and triple point, which lofted moisture and created a greater propensity for CI. The relatively high partial CAPE values, lower LFC, and near-zero CIN and LI values were most suitable for CI near the triple point (Fig. 5b). All of these effects were conducive to convective development but did not explain why the storms first occurred southeast of the triple point, rather than directly above it.

\section{e. Internal gravity waves}

Periodic features north of the OB were apparent in numerous fields, such as satellite (Figs. 2a,b,c), composite radar (Figs. 3b,c), ELDORA reflectivity and vertical vorticity (Figs. 8a,b), and MIPS vertical velocity profiles (Fig. 9). The north-south-oriented bands, visible as green reflectivity bands north of the OB in Fig. 8a, were at a distinct angle to the easterly boundary layer winds north of the OB and to the westerly geostrophic winds at the top of the CBL, suggesting that they were caused by internal gravity waves rather than horizontal convective rolls. Admittedly, the cloud bands were oriented along some measures of boundary layer shear 
direction north of the OB. Such an orientation relative the shear atop the CBL has been observed for horizontal convective rolls (e.g., Kuettner 1971; Ferrare et al. 1991), but most studies have shown that roll axes are aligned along the mean CBL wind (e.g., Weckwerth et al. 1997; Young et al. 2002) or along or to the left of the geostrophic wind at the top of the CBL (e.g., Brown 1972; LeMone 1973).

Interestingly, there was a clear signal of periodic motion both within and above the CBL in the radar reflectivity fields, MIPS, and NRL P3 in situ measurements. In particular, this signature extended from 131 to $2989 \mathrm{~m}$ AGL in the MIPS data, illustrating vertically stacked updrafts, suggesting periodic undulations passing over this fixed site (Fig. 9). Spectral analyses of NRL P3 in situ fields of pressure, temperature, and moisture all showed a prominent peak at wavelengths of 4-8 $\mathrm{km}$ (not shown). This spacing is consistent with the satellite cloud and radar reflectivity bands north of the OB. It is believed that internal gravity waves atop the CBL were interacting with and/or inducing organized coherent structures within the CBL (e.g., LeMone and Meitin 1984; Clark et al. 1986; Kuettner et al. 1987; Balaji and Clark 1988; Hauf and Clark 1989; Redelsperger and Clark 1990).

Alternatively, dynamic instability rolls (e.g., Stensrud and Shirer 1988; Buban et al. 2007) were a possible forcing mechanism of these north-south features, but in this case further evidence of waves is that the propagation of the banded structures $\left(4-5 \mathrm{~m} \mathrm{~s}^{-1}\right.$ from $\left.60^{\circ}-70^{\circ}\right)$ was not consistent with the mean CBL wind (easterly at 3-4 $\mathrm{m} \mathrm{s}^{-1}$ ). Additionally, the character of the cloud bands north of the OB were distinctly different (i.e., more smooth and laminar) than the cloud streets southeast of the triple point, which were more like "pearls on a string," as described in Kuettner's (1959; 1971) observations of horizontal convective rolls. They were also identified as internal gravity waves by Markowski et al. (2006). The source(s) of the waves is (are) unknown, but two possibilities were the shear through the inversion and/or stable-layer air passing over CBL convection, causing an orientation normal to the inversion wind (e.g., Kuettner et al. 1987). In either case, the waves and rolls beneath the waves were tightly coupled.

The 2009 P3 flight track is shown in Fig. 10 with LEANDRE II data overlaid upon ELDORA-derived vertical vorticity, which also showed a periodic signature. Other papers have also noted that waves may exhibit vertical vorticity oscillations (e.g., Wahlén 2004; Constantin et al. 2006; Barcilon and Drazin 2006). Note the good agreement between the $\mathrm{P} 3$ in situ mixing ratio (Fig. 10b) and LEANDRE II mixing ratio (Fig. 10a) and the periodic oscillations of in situ mixing ratio, tem- perature, and vertical velocity (Figs. 10b,c). Interestingly, there was a pronounced relationship between LEANDRE II mixing ratio maxima (darkest red regions along the northern edge of the mixing ratio swath) along the OB and north-south wave features (apparent as negative vertical vorticity bands extending into the maxima mixing ratios), suggesting that the gravity waves were organizing the moisture field. The vertical velocity field was quite noisy and showed no clear relationship. It is hoped that future highresolution moisture measurements will allow for further study of this suggested relationship between negative vertical vorticity and mixing ratio maxima.

This moisture-vertical vorticity relationship was not as clear at other time periods, perhaps due to the transient nature of the waves and the limited range of the LEANDRE II mixing ratio measurements (within a narrow swath extending between 0.8 and $2.8 \mathrm{~km}$ from the NRL P3). There were anomalously low moisture values at the maximum range from the NRL P3 resulting from the high attenuation of the laser beam most likely associated with enhanced aerosol concentrations in PBL thermals at far ranges from the lidar. While there was no obvious evidence of internal gravity waves southeast of the triple point where CI occurred, the relationship between waves and mixing ratio north of the $\mathrm{OB}$ is intriguing and suggests that small-scale internal gravity waves may have played a role in modulating the CBL moisture field.

\section{f. Horizontal convective rolls}

Horizontal convective rolls were evident in both the cloud streets in satellite imagery (Figs. 2b,c,d) with the common pearls-on-a-string appearance south of the $\mathrm{OB}$ (e.g., Kuettner 1959; 1971) and in the northeastsouthwest linearly banded structures just east of the dryline zone in the radar composite fields (Figs. 3b,c). A careful examination of the 330-m AGL flight-level data east of the dryline zone on the southern edge of the OB zone showed thermally forced boundary layer convection with a strong correlation between updrafts, potential temperature, and mixing ratio perturbations within the CBL (Figs. 7b,c,g,h). This, along with the orientation of the reflectivity bands, which were parallel with the CBL wind direction (e.g., southwesterly just east of the convergence line associated with the dryline zone in Fig. 3, and southerly in southern Oklahoma in Fig. 2), strongly suggested the existence of horizontal convective rolls within the CBL in this region (e.g., Weckwerth et al. 1997). It was also apparent that the clear-air reflectivity values were stronger in the region with the rolls (i.e., east of the dryline zone) than west of the dryline zone where rolls were not obvious 

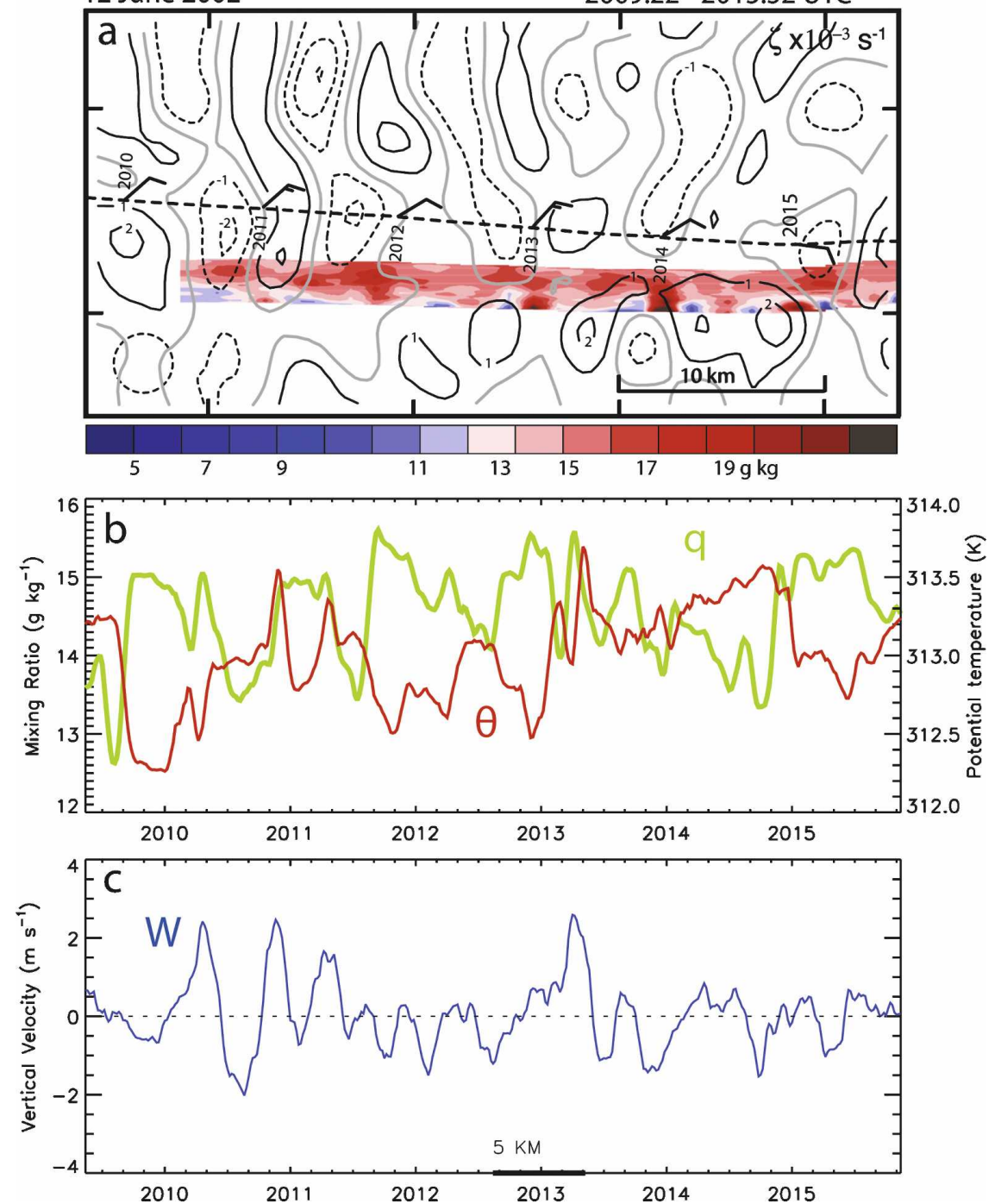

FIG. 10. (a) ELDORA-derived vertical vorticity $\left(\times 10^{-3} \mathrm{~s}^{-1}\right.$; negative values are dashed; zero line is gray) overlaid on LEANDRE II mixing ratio measurements $\left(\mathrm{g} \mathrm{kg}^{-1}\right)$ within the box shown in Fig. 8b. The NRL P3 flight track is shown. Corresponding NRL P3 in situ measurements of (b) potential temperature ( $\mathrm{K}$; red), mixing ratio $\left(\mathrm{g} \mathrm{kg}^{-1}\right.$; green) and (c) vertical velocity $\left(\mathrm{m} \mathrm{s}^{-1}\right)$ are shown.

(Figs. 3a,b,c). It is suspected that this reflectivity enhancement was due to stronger low-level convergence and more insects being forced to resist the roll updrafts in that region (e.g., Wilson et al. 1994). The potential impact of the horizontal convective rolls upon CI on this day will be addressed in the following section.

\section{Convection initiation}

Radar echo and satellite cloud tracking were performed to identify the locations of the first radar echoes and cumulus clouds that led to the three prominent intense echoes at 2100 UTC (labeled 1, 2, 3 in Figs. 3c and 11). The satellite cloud tracking was difficult due to the highly populated cloud field southeast of the triple point, which made it difficult to unambiguously tag a radar echo with a cloud. Additionally, the 5-8-min time interval between GOES-11 satellite images was often insufficient to confidently track individual clouds. While it is possible that the clouds formed along the dryline and advected eastward with the cloud-level wind prior to development into precipitating storms, the cloud tracking exercise suggested otherwise. The cloud tracking suggested that there was a narrow, dry slot just east of the dryline with no convective clouds. Clouds that formed along the dryline could not be 

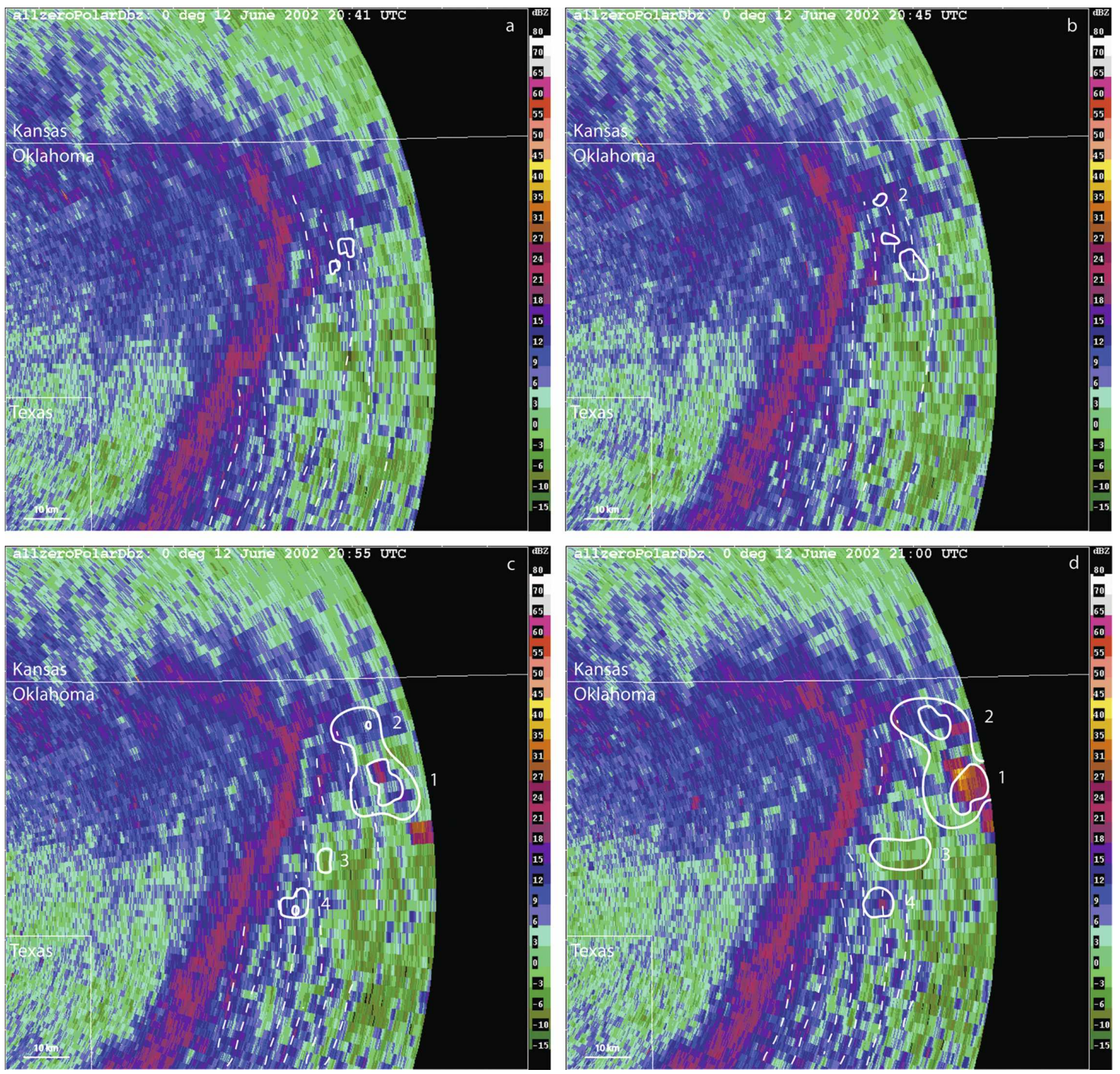

FIG. 11. Low-level $\left(0^{\circ}\right)$ S-Pol reflectivity field at (a) 2041, (b) 2045, (c) 2055, and (d) 2100 UTC. Corresponding coherent radar echoes aloft $\left(3^{\circ}\right)$ are contoured $(0$ and $18 \mathrm{dBZ})$ in white. White dashed lines indicate subjectively drawn roll updraft branches.

tracked across the dry slot. Thus, while not conclusive, cloud tracking suggested that the early clouds that developed into a supercell formed east of the dryline (not shown).

The radar echoes aloft $(\sim 3.5 \mathrm{~km}$ AGL), however, were tracked to their origin with high confidence using S-Pol radar data. Figure 11 shows the low-level S-Pol reflectivity scan with the radar echoes aloft contoured. The first coherent $(0 \mathrm{~dB} Z)$ radar echoes aloft formed at 2041 UTC (Fig. 11a). Radar echo 1 started as two distinct coherent echoes southeast of the triple point and very near the enhanced reflectivity bands, indicating roll updraft branches. Cell 1 continued as two distinct coherent radar echoes aloft while cell 2 initiated further to the north at 2045 UTC (Fig. 11b). The initial location of cell 2 was near the $\mathrm{OB}$ zone and a roll updraft branch. By 2055 UTC (Fig. 11c), cells 1 and 2 merged together and cells 3 and 4 formed farther toward the south. The boundary layer convective motions beneath cells 1 and 2 were more disorganized but still offered a suggestion of roll updrafts beneath the main portion of the echoes. Cells 3 and 4 also formed east of the dryline convergence zone. Cell 3 appeared atop a lowreflectivity region, but cell 4 formed near a roll updraft 


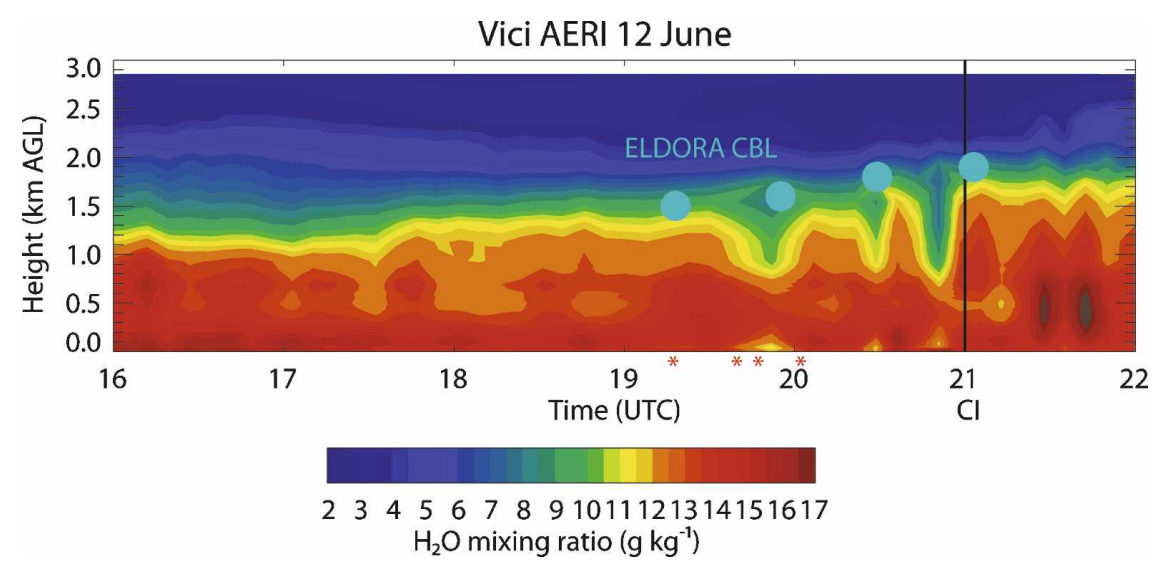

FIG. 12. AERI mixing ratio profiles $\left(\mathrm{g} \mathrm{kg}^{-1}\right)$ from Vici (location is shown in Fig. 2b). CI time is shown by vertical black line. CBL depths, determined from ELDORA airborne radar data observations of roll updrafts, are shown as blue dots. Orange asterisks along the bottom indicate 7.5-min periods of missing data, thus the data were interpolated for those times.

branch. By 2100 UTC (Fig. 11d) cells 1 and 2 continued their growth, cell 3 was expanding, and cell 4 remained near a roll updraft branch. All cells propagated eastward as they grew. By 2115 UTC (not shown), cells 1,2, and 3 reached $35 \mathrm{~dB} Z$, which is the estimated onset of precipitation. The boundary layer convective motions were disorganized by this time. It appeared that three of these four early radar echoes aloft formed near roll updraft branches at various locations away from the triple-point and dryline convergence zones.

The Vici, Oklahoma, AERI mixing ratio profiles illustrated how the depth of the moisture field increased with time to the southeast of the triple point (Fig. 12). The depth of the CBL in the region southeast of the triple point, estimated by the maximum depth of the roll updrafts (e.g., Weckwerth et al. 1996), is overlaid in Fig. 12. These CBL depth estimates were determined from ELDORA radar reflectivity and velocity fields southeast of the triple point. Figure 12 illustrates that the roll depth and moisture depth in the CI air mass were both increasing prior to $\mathrm{CI}$. The $\mathrm{CBL}$ and roll updraft depth estimates observed in a limited manner by ELDORA were lower than all of the LFC measurements (Fig. 5a). Some of the LFC values near the OB were just over $2 \mathrm{~km}$ AGL; therefore, it is possible that a few random roll updraft branches extended $\sim 10 \%$ deeper than those measured. This would have extended the roll updrafts above the nearby LFC measurements and might have provided sufficient lift for CI. It must be noted, however, that there were no soundings within the pure CI air mass southeast of the triple point to accurately assess the LFC height.

In summary, it was shown that the first coherent radar echoes and the precipitation echoes formed up to
$20 \mathrm{~km}$ away from mesoscale boundaries and near roll updraft branches. The roll updraft branches and associated CBL moisture values extended to progressively deeper heights throughout the day prior to CI. Therefore, it is possible that some of the roll updrafts penetrated the LFC in the region and aided in the initiation of deep convection. Thus, it might be important to monitor such kilometer-scale circulations in pinpointing CI. This is consistent with high-resolution ARPS simulations showing the importance of horizontal convective rolls in focusing CI southeast of the triple point (M. Xue 2007, personal communication).

\section{Summary and conclusions}

It has been shown that the CI observed on 12 June 2002 resulted from a complicated mixture of mesoscale and boundary layer circulations and localized areas of instability. While the large-scale conditions were suitable for CI, they did not dictate exactly where and when thunderstorms would form. The combination of the preconvective, clear-air features, including a mesolow, a dryline, $\mathrm{OB}$, internal gravity waves, and horizontal convective rolls, played a role in creating a situation ripe for convective development on this day.

The internal gravity waves and associated CBL circulations observed north of the OB may have organized the low-level moisture field resulting in preferred regions for $\mathrm{CI}$ along the $\mathrm{OB}$. Because convection initiated south of the OB in a region that did not clearly exhibit internal gravity waves, a clear link to CI could not be established. This issue could be more carefully addressed with subsequent datasets of high-resolution moisture measurements. The mesolow located to the 
west of the CI location appeared to enhance the southerly moist flow into the CI region. Circulations associated with the dryline and $\mathrm{OB}$ acted to enhance lowlevel convergence and focused moisture into preferred areas for convective development. Southeast of the triple point the depth of the horizontal convective rolls and the depth of the CBL moisture continually increased prior to CI. The horizontal convective roll updrafts were coincident with the locations of the first radar echoes aloft, suggesting that the rolls helped to focus CI on this day. That is, one possible explanation for CI occurring some distance from mesoscale boundaries may be kilometer-scale circulations commonly occurring within and atop the CBL.

It is not known how common this mixture of circulations-boundaries is, but there are several examples of comparable situations in the literature. For example, during the IHOP_2002 field campaign alone, eight different triple-point intersections were observed (Wilson and Roberts 2006). From IHOP_2002 and other studies, the initiation of convection significantly removed from the triple point was frequently noted (e.g., Trier et al. 2004; Wakimoto et al. 2006; Geerts et al. 2006; Ziegler et al. 2007), and horizontal convective rolls, which are not always easy to detect, may be playing a role more often than realized. Perhaps the mesoscale boundaries may cause broad-scale convergence and moistening while persistent kilometer-scale features provide extra upward motion to trigger convection.

It is not clear why the storms observed in this study initiated when they did. Rolls existed several hours prior to CI and eventually may have produced enough extra lifting to penetrate the LFC at $\sim 2100$ UTC. The IHOP_2002 observations are insufficient to tackle this timing question. Simulations using the Weather Research and Forecasting model (WRF; Skamarock et al. 2005) are also underway to supplement hypotheses based on these observations, which alone cannot fully explain the CI event on this day. The model results are being used to evaluate the relative importance of the various preconvective features and to evaluate the differences in CI between roll and no-roll simulations. Furthermore, the simulations may be used to monitor the depth of the moisture and the depth of the convergence in the region. Through a series of high-resolution simulations, it is hoped that the model results will more clearly illustrate the impact of the various scales of motions and clear-air, preconvective features that led to deep convection on this day.

Acknowledgments. The IHOP_2002 participants are gratefully acknowledged for collecting this dataset. This dataset was collected with much personal discomfort by the ATD, CNRS, and Navy crew and staff on the NRL P3. Thanks to Dick Oye (NCAR/ATD) for making the low-level radar mosaics. The first author appreciates enlightening discussions with James Pinto (NCAR/ RAL), Jim Wilson (NCAR/EOL/RAL), Peggy LeMone (NCAR/MMM), Doug Wesley (UCAR/ COMET), and Mel Shapiro (NCAR/MMM). Detailed reviews of earlier versions of this manuscript by Stan Trier, Conrad Ziegler, Roger Wakimoto, James Pinto, and two anonymous reviewers greatly improved the quality of this paper.

Much of this research was funded through the NCAR/U.S. Weather Research Program (USWRP). NSF Grant ATM-0208651 (TMW co-investigator with Y. Richardson, PSU) is gratefully acknowledged. Some of this work is based upon research supported by the National Science Foundation under Grant ATM0208651 (HVM).

Any opinions, findings and conclusions or recommendations expressed in this publication are those of the author(s) and do not necessarily reflect the views of the National Science Foundation.

\section{REFERENCES}

Atkins, N. T., R. M. Wakimoto, and T. M. Weckwerth, 1995: Observations of the sea-breeze front during CaPE. Part II: DualDoppler and aircraft analysis. Mon. Wea. Rev., 123, 944-969.

,-- , and C. L. Ziegler, 1998: Observations of the finescale structure of a dryline during VORTEX 95. Mon. Wea. Rev., 126, 525-550.

Balaji, V., and T. L. Clark, 1988: Scale selection in locally forced convective fields and the initiation of deep cumulus. $J$. Atmos. Sci., 45, 3188-3211.

Barcilon, A., and P. G. Drazin, 2006: Nonlinear waves of vorticity. Stud. Appl. Math., 106, 437-479.

Bluestein, H. B., 1993: Synoptic-Dynamic Meteorology in Midlatitudes. Vol. 2. Oxford University Press, 594 pp.

— , and S. S. Parker, 1993: Modes of isolated, severe convective storm formation along the dryline. Mon. Wea. Rev., 121, 1354-1372.

_ , E. W. McCaul Jr., G. P. Byrd, and G. R. Woodall, 1988: Mobile sounding observations of a tornadic storm near the dryline: The Canadian, Texas, storm of 7 May 1986. Mon. Wea. Rev., 116, 1790-1804.

, R. L. Walko, and R. P. Davies-Jones, 1990: An observational study of splitting convective clouds. Mon. Wea. Rev., 118, 1359-1370.

Bosart, B. L., W.-C. Lee, and R. M. Wakimoto, 2002: Procedures to improve the accuracy of airborne Doppler radar data. $J$. Atmos. Oceanic Technol., 19, 322-339.

Brown, R. A., 1972: On the inflection point instability of a stratified Ekman boundary layer. J. Atmos. Sci., 29, 851-859.

Bruneau, D., P. Quaglia, C. Flamant, M. Meissonier, and J. Pelon, 2001: Airborne lidar LEANDRE II for water-vapor profiling in the troposphere. Appl. Opt., 40, 3450-3475.

Buban, M. S., C. L. Ziegler, E. N. Rasmussen, and Y. P. Richardson, 2007: The dryline on 22 May 2002 during IHOP: 
Ground-radar and in situ data analyses of the dryline and boundary layer evolution. Mon. Wea. Rev., 135, 2473-2505.

Byers, H. R., and R. R. Braham Jr., 1949: The Thunderstorm. U.S. Government Printing Office, 287 pp.

Cai, H., W.-C. Lee, T. M. Weckwerth, C. Flamant, and H. V. Murphey, 2006: Observations of the 11 June dryline during IHOP_2002-A null case for convection initiation. Mon. Wea. Rev., 134, 336-354.

Carbone, R. E., J. W. Wilson, T. D. Keenan, and J. M. Hacker, 2000: Tropical island convection in the absence of significant topography. Part I: Life cycle of diurnally forced convection. Mon. Wea. Rev., 128, 3459-3480.

Clark, T. L., T. Hauf, and J. P. Kuettner, 1986: Convectively forced internal gravity waves: Results from two-dimensional numerical experiments. Quart. J. Roy. Meteor. Soc., 112, 899 925.

Constantin, A., D. Sattinger, and W. Strauss, 2006: Variational formulations for steady water waves with vorticity. J. Fluid Mech., 548, 151-163.

Cressman, G. P., 1959: An operational objective analysis scheme. Mon. Wea. Rev., 87, 367-384.

Crook, N. A., 1996: Sensitivity of moist convection forced by boundary layer processes to low-level thermodynamic fields. Mon. Wea. Rev., 124, 1768-1785.

— T. L. Clark, and M. W. Moncrieff, 1991: The Denver Cyclone. Part II: Interaction with the convective boundary layer. J. Atmos. Sci., 48, 2109-2126.

Dailey, P. S., and R. G. Fovell, 1999: Numerical simulation of the interaction between the sea-breeze front and horizontal convective rolls. Part I: Offshore ambient flow. Mon. Wea. Rev., 127, 858-878.

Doswell, C. A., III, and E. N. Rasmussen, 1994: The effect of neglecting the virtual temperature correction on CAPE calculations. Wea. Forecasting, 9, 625-629.

Fankhauser, J. C., N. A. Crook, J. Tuttle, L. J. Miller, and C. G. Wade, 1995: Initiation of deep convection along boundary layer convergence lines in a semitropical environment. Mon. Wea. Rev., 123, 291-313.

Feltz, W. F., H. B. Howell, R. O. Knuteson, H. M. Woolf, and H. E. Revercomb, 2003: Near continuous profiling of temperature, moisture, and atmospheric stability using the Atmospheric Emitted Radiance Interferometer (AERI). $J$. Appl. Meteor., 42, 584-597.

Ferrare, R. A., J. L. Schols, E. W. Eloranta, and R. Coulter, 1991: Lidar observations of banded convection during BLX83. $J$. Appl. Meteor., 30, 312-326.

Fovell, R. G., and P. S. Dailey, 2001: Numerical simulation of the interaction between the sea-breeze front and horizontal convective rolls. Part II: Alongshore ambient flow. Mon. Wea. Rev., 129, 2057-2072.

Geerts, B., R. Damiani, and S. Haimov, 2006: Finescale vertical structure of a cold front as revealed by an airborne Doppler radar. Mon. Wea. Rev., 134, 251-271.

Hane, C. E., C. J. Kessinger, and P. S. Ray, 1987: The Oklahoma squall line of 19 May 1977. Part II: Mechanisms for maintenance of the region of strong convection. J. Atmos. Sci., 44, 2866-2886.

—, C. L. Ziegler, and H. B. Bluestein, 1993: Investigation of the dryline and convective storms initiated along the dryline: Field experiments during COPS-91. Bull. Amer. Meteor. Soc., 74, 2133-2145.

- H. B. Bluestein, T. M. Crawford, M. E. Baldwin, and R. M. Rabin, 1997: Severe thunderstorm development in relation to along-dryline variability: A case study. Mon. Wea. Rev., 125, 231-251.

—, M. E. Baldwin, H. B. Bluestein, T. M. Crawford, and R. M. Rabin, 2001: A case study of severe storm development along a dryline within a synoptically active environment. Part I: Dryline motion and an Eta Model forecast. Mon. Wea. Rev., 129, 2183-2204.

R. M. Rabin, T. M. Crawford, H. B. Bluestein, and M. E. Baldwin, 2002: A case study of severe storm development along a dryline within a synoptically active environment. Part II: Multiple boundaries and convection initiation. Mon. Wea. Rev., 130, 900-920.

Hauf, T., and T. L. Clark, 1989: Three-dimensional numerical experiments on convectively forced internal gravity waves. Quart. J. Roy. Meteor. Soc., 115, 309-333.

Hildebrand, P. H., and Coauthors, 1996: The ELDORA/ ASTRAIA airborne Doppler weather radar: High-resolution observations for TOGA COARE. Bull. Amer. Meteor. Soc., 77, 213-232.

Hock, T. F., and J. L. Franklin, 1999: The NCAR GPS dropwindsonde. Bull. Amer. Meteor. Soc., 80, 407-420.

Holton, J. R., 2004: An Introduction to Dynamic Meteorology. Elsevier Academic Press, 535 pp.

Johnson, R. H., and D. L. Priegnitz, 1981: Winter monsoon convection in the vicinity of North Borneo. Part II: Effects on large-scale fields. Mon. Wea. Rev., 109, 1615-1628.

Karyampudi, V. M., S. E. Koch, J. W. Rottman, and M. L. Kaplan, 1995: The influence of the Rocky Mountains in the 13-14 April 1986 severe weather outbreak. Part II: Evolution of an internal bore and its role in triggering a squall line. Mon. Wea. Rev., 123, 1423-1446.

Kelly, R. D., 1984: Horizontal roll and boundary-layer interrelationships observed over Lake Michigan. J. Atmos. Sci., 41, 1816-1826.

Kingsmill, D. E., 1995: Convection initiation associated with a seabreeze front, a gust front, and their collision. Mon. Wea. Rev., 123, 2913-2933.

- , and N. A. Crook, 2003: An observational study of atmospheric bore formation from colliding density currents. Mon. Wea. Rev., 131, 2985-3002.

Knupp, K. R., J. Walters, and E. W. McCaul Jr., 2000: Doppler profiler observations of Hurricane Georges at landfall. Geophys. Res. Lett., 27, 3361-3364.

Koch, S. E., and J. McCarthy, 1982: The evolution of an Oklahoma dryline. Part II: Boundary-layer forcing of mesoconvective systems. J. Atmos. Sci., 39, 237-257.

— during COPS-91: Frontal structure and the process of severe storm initiation. J. Atmos. Sci., 56, 2862-2890.

Kuettner, J. P., 1959: The band structure of the atmospheric. Tellus, 11, 267-294.

1971: Cloud bands in the earth's atmosphere. Tellus, 23, 404-425.

, P. A. Hildebrand, and T. L. Clark, 1987: Convection waves: Observations of gravity wave systems over convectively active boundary layers. Quart. J. Roy. Meteor. Soc., 113, 445467.

Lee, B. D., R. D. Farley, and M. R. Hjelmfelt, 1991: A numerical case study of convection initiation along colliding convergence boundaries in northeast Colorado. J. Atmos. Sci., 48, 2350-2366.

Lee, W.-C., P. Dodge, F. D. Marks, and P. H. Hildebrand, 1994: 
Mapping of airborne Doppler radar data. J. Atmos. Oceanic Technol., 11, 572-578.

Leise, J. A., 1982: A multidimensional scale-telescoped filter and data extension package. NOAA Tech. Memo. ERL-82, 11 pp. [Available from NOAA ERL, 325 Broadway, Boulder, CO 80303.]

LeMone, M. A., 1973: The structure and dynamics of horizontal roll vortices in the planetary boundary layer. J. Atmos. Sci., 30, 1077-1091.

— soscale boundary layer convection in the tropics. Mon. Wea. Rev., 112, 1985-1997.

Liu, H., and M. Xue, 2008: Prediction of convective initiation and storm evolution on 12 June 2002 during IHOP_2002. Part I: Control simulation and sensitivity experiments. Mon. Wea. Rev., 136, 2261-2282.

Lutz, J., P. Johnson, B. Lewis, E. Loew, M. Randall, and J. VanAndel, 1995: NCAR's S-Pol: Portable polarimetric Sband radar. Preprints, Ninth Symp. on Meteorological Observations and Instrumentation, Charlotte, NC, Amer. Meteor. Soc., 408-410.

Mahoney, W. P., 1988: Gust front characteristics and the kinematics associated with interacting thunderstorm outflows. Mon. Wea. Rev., 116, 1474-1491.

Malkus, J. S., and H. Riehl, 1964: Cloud structure and distributions over the tropical Pacific Ocean. Tellus, 16, 275-287.

Markowski, P., and C. Hannon, 2006: Multiple-Doppler radar observations of the evolution of vorticity extrema in a convective boundary layer. Mon. Wea. Rev., 134, 355-374.

- - — and E. Rasmussen, 2006: Observations of convection initiation "failure" from the 12 June 2002 IHOP deployment. Mon. Wea. Rev., 134, 375-405.

May, P. T., 1999: Thermodynamic and vertical velocity structure of two gust fronts observed with a wind profiler/RASS during MCTEX. Mon. Wea. Rev., 127, 1796-1807.

Mohr, C. G., and L. J. Miller, 1983: CEDRIC-A software package of Cartesian space editing, synthesis and display of radar fields under interactive control. Preprints, 21st Conf. on Radar Meteorology, Edmonton, AB, Canada, Amer. Meteor. Soc., 569-574.

,-- R. L. Vaughn, and H. W. Frank, 1986: The merger of mesoscale datasets into a common Cartesian format for efficient and systematic analysis. J. Atmos. Oceanic Technol., 3, 146-161.

Mueller, C., T. Saxen, R. Roberts, J. Wilson, T. Betancourt, S. Dettling, N. Oien, and J. Yee, 2003: NCAR Auto-Nowcast system. Wea. Forecasting, 18, 545-561.

Murphey, H. V., R. M. Wakimoto, C. Flamant, and D. E. Kingsmill, 2006: Dryline on 19 June 2002 during IHOP. Part I: Airborne Doppler and LEANDRE II analyses of the thin line structure and convection initiation. Mon. Wea. Rev., 134, 406-430.

Oye, R., C. Mueller, and S. Smith, 1995: Software for radar translation, visualization, editing and interpolation. Preprints, 27th Conf. on Radar Meteorology, Vail, CO, Amer. Meteor. Soc., 359-361.

Purdom, J. F. W., and K. Marcus, 1982: Thunderstorm trigger mechanisms over the southeast U.S. Preprints, 12th Conf. on Severe Local Storms, San Antonio, TX, Amer. Meteor. Soc., 487-488.

Redelsperger, J.-L., and T. L. Clark, 1990: The initiation and horizontal scale selection of convection over gently sloping terrain. J. Atmos. Sci., 47, 516-541.
Rhea, J. O., 1966: A study of thunderstorm formation along drylines. J. Appl. Meteor., 5, 58-63.

Rotunno, R., J. B. Klemp, and M. L. Weisman, 1988: A theory for strong, long-lived squall lines. J. Atmos. Sci., 45, 463-485.

Skamarock, W. C., J. B. Klemp, J. Dudhia, D. O. Gill, D. M. Barker, W. Wang, and J. G. Powers, 2005: A description of the advanced research WRF Version 2. NCAR Tech. Note NCAR/TN-468+STR, 100 pp. [Available online at http:// www.mmm.ucar.edu/wrf/users/docs/arw_v2.pdf.]

Stensrud, D. J., and H. N. Shirer, 1988: Development of boundary layer rolls from dynamic instabilities. J. Atmos. Sci., 45, 10071019.

Testud, J., P. H. Hildebrand, and W.-C. Lee, 1995: A procedure to correct airborne Doppler radar data for navigation errors using the echo returned from the earth's surface. J. Atmos. Oceanic Technol., 12, 800-820.

Trier, S. B., D. B. Parsons, and J. H. E. Clark, 1991: Environment and evolution of a cold-frontal mesoscale convective system. Mon. Wea. Rev., 119, 2429-2455.

_ , F. Chen, and K. Manning, 2004: A study of convective initiation in a mesoscale model using high-resolution land surface initial conditions. Mon. Wea. Rev., 132, 2954-2976.

Wahlén, E., 2004: On steady gravity waves with vorticity. Int. Math. Res. Notices, 54, 2881-2896.

Wakimoto, R. M., and N. T. Atkins, 1994: Observations of the sea-breeze front during CaPE. Part I: Single-Doppler, satellite, and cloud photogrammetric analysis. Mon. Wea. Rev., 122, 1092-1114.

C. Liu, and H. Cai, 1998: The Garden City, Kansas, storm during VORTEX 95. Part I: Overview of the storm's life cycle and mesocyclogenesis. Mon. Wea. Rev., 126, 372-392.

- , H. V. Murphey, E. V. Browell, and S. Ismail, 2006: The "Triple Point" on 24 May 2002 during IHOP. Part I: Airborne Doppler and LASE analyses of the frontal boundaries and convection initiation. Mon. Wea. Rev., 134, 231-250.

Weckwerth, T. M., 2000: The effect of small-scale moisture variability on thunderstorm initiation. Mon. Wea. Rev., 128, 4017-4030.

_, and R. M. Wakimoto, 1992: The initiation and organization of convective cells atop a cold-air outflow boundary. Mon. Wea. Rev., 120, 2169-2187.

— , and D. B. Parsons, 2006: A review of convection initiation and motivation for IHOP_2002. Mon. Wea. Rev., 134, 5-22.

_ J. W. Wilson, and R. M. Wakimoto, 1996: Thermodynamic variability within the convective boundary layer due to horizontal convective rolls. Mon. Wea. Rev., 124, 769-784.

$\_,-,-,$and N. A. Crook, 1997: Horizontal convective rolls: Determining the environmental conditions supporting their existence and characteristics. Mon. Wea. Rev., 125, 505526.

- and Coauthors, 2004: An overview of the International $\mathrm{H}_{2} \mathrm{O}$ Project (IHOP_2002) and some preliminary highlights. Bull. Amer. Meteor. Soc., 85, 253-277.

Weiss, C. C., and H. B. Bluestein, 2002: Airborne pseudo-dualDoppler analysis of a dryline-outflow boundary intersection. Mon. Wea. Rev., 130, 1207-1226.

Wilson, J. W., and W. E. Schreiber, 1986: Initiation of convective storms at radar-observed boundary-layer convergence lines. Mon. Wea. Rev., 114, 2516-2536.

_ , and C. K. Mueller, 1993: Nowcasts of thunderstorm initiation and evolution. Wea. Forecasting, 8, 113-131. 
- and D. L. Megenhardt, 1997: Thunderstorm initiation, organization and lifetime associated with Florida boundary layer convergence lines. Mon. Wea. Rev., 125, 1507-1525.

- and R. D. Roberts, 2006: Summary of convective storm initiation and evolution during IHOP: Observational and modeling perspective. Mon. Wea. Rev., 134, 23-47.

, G. B. Foote, N. A. Crook, J. C. Fankhauser, C. G. Wade, J. D. Tuttle, C. K. Mueller, and S. K. Krueger, 1992: The role of boundary-layer convergence zones and horizontal rolls in the initiation of thunderstorms: A case study. Mon. Wea. Rev., 120, 1785-1815.

-, T. M. Weckwerth, J. Vivekanandan, R. M. Wakimoto, and R. W. Russell, 1994: Boundary layer clear-air radar echoes: Origin of echoes and accuracy of derived winds. J. Atmos. Oceanic Technol., 11, 1184-1206.

Xiao, Q., and J. Sun, 2007: Multiple-radar data assimilation and short-range quantitative precipitation forecasting of a squall line observed during IHOP_2002. Mon. Wea. Rev., 135, 33813404.
Xue, M., and W. J. Martin, 2006: A high-resolution modeling study of the 24 May 2002 dryline case during IHOP. Part II: Horizontal convective rolls and convective initiation. Mon. Wea. Rev., 134, 172-191.

Young, G. S., D. A. R. Kristovich, M. R. Hjelmfelt, and R. C. Foster, 2002: Rolls, streets, waves, and more: A review of quasi-two-dimensional structures in the atmospheric boundary layer. Bull. Amer. Meteor. Soc., 83, 997-1001.

Ziegler, C. L., and E. N. Rasmussen, 1998: The initiation of moist convection at the dryline: Forecasting issues from a case study perspective. Wea. Forecasting, 13, 1106-1131.

, T. J. Lee, and R. A. Pielke Sr., 1997: Convection initiation at the dryline: A modeling study. Mon. Wea. Rev., 125, 10011026.

E. N. Rasmussen, M. S. Buban, Y. P. Richardson, L. J. Miller, and R. M. Rabin, 2007: The "Triple Point" on 24 May 2002 during IHOP. Part II: Ground-radar and in-situ boundary layer analysis of cumulus development and convection initiation. Mon. Wea. Rev., 135, 2443-2472. 